NBER WORKING PAPER SERIES

\title{
BANKS' ADVANTAGE IN HEDGING LIQUIDITY RISK: THEORY AND EVIDENCE FROM THE COMMERCIAL PAPER MARKET
}

\author{
Evan Gatev \\ Philip E. Strahan \\ Working Paper 9956 \\ http://www.nber.org/papers/w9956 \\ NATIONAL BUREAU OF ECONOMIC RESEARCH \\ 1050 Massachusetts Avenue \\ Cambridge, MA 02138 \\ September 2003
}

We thank Viral Acharya, Pierluigi Balduzzi, Daniel Covitz, Wayne Ferson, Mark Flannery, Ed Kane, Arvind Krishnamurthy, George Pennacchi, Jeff Pontiff, and Jeremy Stein for helpful comments, as well as seminar participants at Boston College, the NBER, the Western Finance Association 2003 Annual Meeting, and the Federal Reserve Banks of New York and Chicago. The views expressed herein are those of the authors and not necessarily those of the National Bureau of Economic Research.

(C2003 by Evan Gatev and Philip E. Strahan. All rights reserved. Short sections of text, not to exceed two paragraphs, may be quoted without explicit permission provided that full credit, including $\odot$ notice, is given to the source. 
Banks' Advantage in Hedging Liquidity Risk:

Theory and Evidence from the Commercial Paper Market

Evan Gatev and Philip E. Strahan

NBER Working Paper No. 9956

September 2003

JEL No. G2

\begin{abstract}
This paper argues that banks have a unique ability to hedge against market-wide liquidity shocks. Deposit inflows provide funding for loan demand shocks that follow declines in market liquidity. Consequently, one dimension of bank "specialness" is that banks can insure firms against systematic declines in market liquidity at lower cost than other financial institutions. We provide supporting empirical evidence from the commercial paper (CP) market. When market liquidity dries up and $\mathrm{CP}$ spreads increase, banks experience funding inflows. These flows allow banks to meet increased loan demand from borrowers drawing funds from pre-existing commercial paper backup lines, without running down their holdings of liquid assets. Moreover, the supply of cheap funds is sufficiently large so that pricing on new lines of credit actually falls as market spreads widen.

\author{
Evan Gatev \\ Carroll School of Management \\ Boston College \\ Fulton Hall \\ Chestnut Hill, MA 02467 \\ evan.gatev@bc.edu \\ Philip E. Strahan \\ Carroll School of Management \\ Boston College \\ Fulton Hall \\ Chestnut Hill, MA 02467 \\ and NBER \\ philip.strahan@bc.edu
}




\section{INTRODUCTION}

The rise of the commercial paper market, which resumed following the demise of the Penn Central Railroad in the early 1970s, followed by the growth of the junk bond market in the 1980s and 1990s, has seemingly reduced the role of banks in providing financing to large businesses (Mishkin and Strahan, 1998). This much-remarked-upon evolution away from banks and toward the securities markets, though, has not rendered banks irrelevant (Boyd and Gertler, 1994). While they do provide less funding than before, banks remain important, even for large firms, as the "liquidity provider of last resort." 1 This liquidity insurance role is notable in the commercial paper market, where issuers invariably secure a backup line of credit from their bank as protection against market pullbacks. Banks have also traditionally provided liquidity insurance in the form of loan commitments to many classes of borrowers. In the case of the commercial paper backup lines, these contracts allow firms to borrow (or "take down") up to a pre-determined amount of funds at a fixed spread over a safe market benchmark interest rate such as LIBOR. This liquidity insurance softens the blow of reduced liquidity, where liquidity can be defined as the firm's ability to access the capital markets at attractive (fair) prices. ${ }^{2}$

Why do commercial banks, as opposed to some other kind of financial institutions, provide this liquidity insurance? In this paper, we argue that banks can provide firms insurance against market-wide liquidity shocks at lower cost than other financial intermediaries because deposit inflows provide a hedge for loan demand shocks. Figure 1 illustrates our main argument

\footnotetext{
${ }^{1}$ Banks also continue to bear significant credit risk through off-balance sheet guarantees such as standby letters of credit.

${ }^{2}$ According to this definition, a decline of liquidity is typically caused by an increase in arm's length investors' perceived opaqueness of firms. Asymmetric information can lead to equilibrium credit rationing in the commercial paper market. Stiglitz and Weiss (1981) show that credit rationing is optimal due to both adverse selection and moral hazard. 
graphically. During normal times (high liquidity), funds flow directly from investors to firms

(broken line in Figure 1). Because banks are viewed as a safe haven by investors, funding tends to become available to them during periods of market stress (low liquidity), just when borrowers want to draw funds from their loan commitments. Hence, the funding flows within a bank complement each other, with deposit inflows serving as a hedge for outflows from loan commitment take-downs (solid lines in Figure 1). Because of this hedge, banks can offer the lowest-cost insurance against a systematic shock to liquidity. The banks' ability to sell liquidity insurance more cheaply than other financial institutions provides an explanation for the viability of their business in this particular market.

Our argument complements Kashyap, Rajan and Stein (2002), who propose a riskmanagement motive as a defining characteristic of a commercial bank: a financial intermediary that combines demand deposits with loan commitments and lines of credit (we use these two terms synonymously). ${ }^{3}$ In effect, banks offer liquidity to both households and firms with these two products. As long as the demand for liquidity from depositors and borrowers is not too highly correlated, the intermediary will pool these two classes of customers together to conserve on its need to hold costly liquid assets - the buffer against unexpected deposit withdrawals and loan take downs. ${ }^{4}$ Our argument extends the KRS rationale to highlight an additional specialty of

\footnotetext{
${ }^{3}$ Some early studies analyzed loan commitments as a hedge against changes in interest rates or credit quality (see, for example Thakor (1982) and Kanatas (1987)), and others analyzed the pricing structure of loan commitments as a way to separate high-quality from low-quality borrowers (see, for example, Boot, Thakor and Udell (1987) and Thakor and Udell (1987)). Other studies have emphasized loan commitments as protection for borrowers against credit rationing by their bank (see, for example, Berger and Udell (1992) and Morgan (1998)). For more recent studies on pricing of loan commitments as options, see Shockley and Thakor (1997) and Chava (2002).
}

${ }^{4}$ Holding liquid assets is costly because these assets earn low returns and create additional agency problems for the financial institution (Myers and Rajan, 1998). 
banks - their unique ability to hedge against systematic liquidity shocks. As a result, banks can insure firms against market-wide declines in the availability of liquidity at lower cost than other institutions. While the KRS risk-management argument is quite general, it applies to any firm that can diversify efficiently across different lines of business. Our contribution is to uncover a new dimension of bank "specialness" that has not been emphasized in the literature. ${ }^{5}$

Section II below provides some background by describing banks' liquidity insurance role in the commercial paper market. The main argument is presented Section III, where a simple model shows how the correlation between a lender's funding cost and the availability of market liquidity affects its ability to price this insurance. In a competitive equilibrium, the price of loan commitments varies negatively with the covariance between the cost funds to the lender and the availability of market liquidity. This is the main testable implication of the model.

In Sections IV and V, we show empirically that bank fund costs decrease when market liquidity becomes scarce, where liquidity is measured by the difference between the commercial paper rate to high-grade borrowers and the Treasury Bill rate (the "paper-bill spread"). We provide three pieces of supporting evidence. First, we show that bank asset growth increases in response to widening of spreads in the commercial paper market, controlling for the overall level of interest rates. Moreover, the increase in assets occurs not only in the loan and C\&I loan portfolio, but also among banks' holdings of liquid assets (cash and securities). Thus, rather than

\footnotetext{
${ }^{5}$ Previous research has identified several other dimensions of bank specialness, emphasizing a link between the liability and asset sides of the banking. For example, Fama (1985) suggested that information stemming from the business checking account could give banks an advantage in lending over other financial intermediaries; for recent empirical evidence, see Mester, Nakamura and Renault (2002). Mester and Berlin (1999) argue that banks' access to inelastically supplied funds (core deposits) allows them to offer borrowers insurance against changes in interest rates. Other studies suggest that because bank loans are illiquid, and thus make "bad" collateral against which to borrow, the optimal capital structure is one characterized by very liquid (or short-term) liabilities that subject the bank to the possibility of a run (e.g. Calomiris and Kahn, 1991, Flannery, 1994, and Diamond and Rajan, 2001).
} 
running down their buffer of liquid assets in response to market shocks, as banks would do in the face of unexpected increases in loan demand alone, banks increase their holding of liquid assets. This increase in liquid assets is strong evidence of greater availability of funding to banks. Second, we show that the quantity of assets funded with deposits (particularly transactions deposits) increases with the paper-bill spread, reflecting the increased availability of deposit finance during periods of high spreads. Third, we test how the funding costs of banks versus finance companies changes with the commercial paper spread. We find that yields on bankissued paper (i.e., large negotiable CDs) decreases with the commercial paper spread, whereas the yields on finance-company-issued paper do not. This differential response to commercial paper shocks is our most direct evidence that banks have a comparative advantage over their closest competitor in offering liquidity insurance.

In our last set of results, we estimate how the price of new commercial paper backup lines of credit vary with changes in the price of market-provided liquidity, again as measured by the paper-bill spread. Consistent with our findings on banking funding, we show that the price of the new lines decreases with the paper-bill spread. Thus, when credit markets tighten, the increased availability of funding to banks seems to be large enough to allow banks to fund their obligations under existing lines of credit and to issue new lines at low prices.

\section{Banks' Insuring Liquidity in the Commercial Paper Market}

Under normal circumstances, commercial paper offers the lowest cost source of shortterm financing for large, well-established firms. The commercial paper backup line of credit, however, allows a firm to borrow from its bank at a pre-determined spread, thus providing 
insurance against the possibility of having to borrow when commercial paper is expensive (e.g. because outstanding paper is maturing). Borrowing in the commercial paper market may be expensive either because a firm's credit quality has declined, or because the overall supply of liquidity has declined. ${ }^{6}$ Firms pay their bank an annual fee for this insurance.

Banks' functioning as liquidity insurance providers originated early in the development of the commercial paper market. In 1970, Penn Central Transportation Company filed for bankruptcy with more than $\$ 80$ million in commercial paper outstanding. As a result of their default, investors lost confidence in other large commercial paper issuers, making it difficult for some of these firms to refinance their paper as it matured. The Federal Reserve responded to the Penn Central crisis by lending aggressively to banks through the discount window and encouraging them, in turn, to provide liquidity to their large borrowers (Kane, 1974). In response to this difficulty, commercial paper issuers thereafter began purchasing backup lines of credit from banks to insure against future funding disruptions (Saidenberg and Strahan, 1999).

Similar market shocks have happened periodically since the Penn Central debacle. Typically, some event in the markets hampers investor confidence in their ability to sort out highquality from low-quality firms. During the recent Enron crisis, for example, the accuracy of financial statements came into question and, as a result, many firms faced difficulty borrowing in the commercial paper market. In March of 2002, the Wall Street Journal reported the following: "For years, the commercial-paper market has served as the corporate world's automated teller machine, spitting out a seemingly endless supply of cash for businesses at super-low interest

\footnotetext{
${ }^{6}$ Banks protect themselves from large declines in credit quality with the "material adverse change" covenant. This covenant allows a bank to get out of its obligations to provide funds to a borrower that has experienced a significant downgrade.
} 
rates... But now, amid financial jitters caused by Enron Corp.'s collapse, that machine is sputtering, sending a surprising number of companies of all sizes scrambling to find money for their most basic needs, from paying salaries to buying office supplies. Some are paying higher interest rates so they can keep selling paper. But others, after getting the cold shoulder from commercial-paper investors, have turned to raising debt by other, costlier, means... Like running water, it's (commercial paper) only missed when it stops flowing. The market first began experiencing difficulties about a year ago, as the economy slowed. Enron's collapse fueled more worry -- in part because it caused credit-rating agencies to become more hawkish. Stung by criticism that both Moody's and Standard \& Poor's kept Enron at investment grade until just five days before it filed for bankruptcy last fall, the rating agencies started poring over balance sheets, looking for companies that seem over-dependent on commercial paper."”

Before Enron, the Russian default in late summer of 1998 followed by the failure of the hedge fund Long-Term Capital Management (LTCM) created a similar increase in uncertainty, leading to a so-called "flight to quality." During these episodes, investor funds flow toward safe investments such as bank deposits (and government securities), rather than to risky investments such as commercial paper, corporate bonds or equities. As we show below, banks experience inflows of funds during these periods, and, at the same time, firms have a high demand to take down funds from pre-existing lines of credit. Said in a slightly different way, when market liquidity dries up, the supply of bank loans increases (because funding flows into banks) at the same time that demand for bank loans increases (because firms want to take down funds). Re-

\footnotetext{
${ }^{7}$ See "Cash Drought: A Dwindling Supply of Short-Term Credit Plagues Corporations-Market in Commercial Paper hurt by Enron Fears," Gregory Zuckerman, Wall Street Journal, March 28, 2002.
} 
intermediation occurs during periods of market turmoil because investors trust banks, perhaps

because banks are explicitly and implicitly insured by the government or because banks have the information to sort out high-quality and low-quality firms. In short, when investments are perceived as opaque, firms have to finance indirectly through the banks.

\section{A Model of LoAn-Commitment Pricing}

Our goal is to construct a simple asset-pricing model of loan commitments that highlights the main thesis of this paper: an intermediary whose funding cost declines when market liquidity becomes scarce has a comparative advantage over competing intermediaries in issuing this product. $^{8}$ We then offer supporting evidence that banks, have access to funding that exhibits this property.

Assume for simplicity that market liquidity is the only systematic risk factor. ${ }^{9}$ The present value of a 1-period loan with $\$ 1$ commitment, $P_{L C}$, is determined according to a general asset-pricing model of the form:

$$
P_{L C}=\frac{1}{1+r}\left(E\left[r_{L C}\right]-\gamma \operatorname{Cov}\left[r_{L C}, L\right]\right),
$$

${ }^{8}$ Note that the risk management motive of Kashyap et al. (2002) is subsumed in our model. However, our focus is not on the capital structure, but on the bank's exposure to external shocks in the capital markets. Thus, our starting point is not the deviation from the Modigliani-Miller paradigm, but modeling the external liquidity shocks.

${ }^{9}$ Covitz and Downing (2002) argue that movements in yields on short- and long-term corporate debt can only be explained by accounting for liquidity risk as well as default risk. As evidence, they show that yields on commercial paper reflect firm-level liquidity risk as well as default risk, whereas yields on long-term corporate bonds reflect only firm-level characteristics related to default risk. Note also that other risk factors can be added to our model without changing the basic story, although they would not contribute to banks' comparative advantage in commitment lending. To the extent that a decline in market liquidity captures a systematic widening of spreads, the latter can be due to any number of underlying factors. In effect we can interpret a single priced systematic liquidity factor as the projection of the stochastic discount factor that captures a number of underlying systematic factors on the commercial paper market. 
where $L$ is the liquidity risk factor, $\gamma$ is the equilibrium price of $L$-risk and $r$ is the riskless rate.

The realized return on a loan commitment, $r_{L C}$, is random and has two components. The first is a fixed return, $r_{U D}$, which is derived from the pre-paid fee on undrawn funds. The risky part of the return can itself be decomposed into two further parts, the return on the drawn funds $\left(r_{L}\right)$ and the cost to the intermediary of funding the loan, i.e. the yield on deposits, $\left(r_{D}\right)$. The return on the loan is risky because of the possibility of default; the cost of funding the loan is risky because it varies systematically with the availability of liquidity in the market $(L)$. Moreover, the fraction of funds taken down, denoted as $\alpha$, also is a random variable with values between 0 and 1 . We can write the return on the loan commitment as follows:

$$
r_{L C}=(1-\alpha) r_{U D}+\alpha\left(r_{L}-r_{D}\right) .
$$

To simplify the exposition, we will assume that the take-down rate, $\alpha$, is a decreasing deterministic function of $L$. In words, when liquidity is plentiful ( $L$ is high), the take-down rate is low because borrowers use the commercial paper markets, and when liquidity is scarce, the take-down rate is high because commercial paper borrowing is expensive. We can decompose the systematic risk associated with a loan commitment into three parts, as follows:

$$
\operatorname{Cov}\left[r_{L C}, L\right]=\operatorname{Cov}\left[(1-\alpha) r_{U D}, L\right]+\operatorname{Cov}\left(\alpha r_{L}, L\right)-\operatorname{Cov}\left[\alpha r_{D}, L\right]
$$

The first two covariance terms depend only on the actions taken by the borrower - that is, the sensitivity of the borrower's take-down behavior to liquidity $(\alpha)$ and the return on the loan conditional on funds being drawn $\left(r_{L}\right)$. Thus, the magnitudes of these two terms are independent of the type of intermediary that has sold the loan commitment. The third term depends on how 
the intermediary's funding costs $\left(r_{D}\right)$ varies with $L$. Analytically, we are interested in the sign of the following expression:

$$
\frac{d \operatorname{Cov}\left[\alpha r_{D}, L\right]}{d \operatorname{Cov}\left[r_{D}, L\right]}
$$

We assumed above that the take-down fraction is a deterministic function of the liquidity shock; we also assume that the joint distribution of $r_{D}$ and $L$ is normal: ${ }^{10}$

$$
\begin{aligned}
& \left.\left(r_{D}, L\right) \sim N\left(\overline{\left(r_{D}\right.}, 0\right), \Sigma\right) \\
& \operatorname{Cov}\left(r_{D}, L\right)=\sigma_{r_{D}, L}
\end{aligned}
$$

Now, using the normality of $L$ we can write (see the Appendix A)

$$
\operatorname{Cov}\left(\alpha r_{D}, L\right)=\frac{\sigma_{r_{D} L}}{\sigma_{L}^{2}} E\left[\alpha(L) L^{2}\right]+E\left[r_{D}\right] E[\alpha(L) L]
$$

Notice that this is a linear function of $\sigma_{r_{D} L}$, with a negative intercept (because $\alpha$ is decreasing and $\mathrm{E}[L]=0$ ). The key result is that the slope is positive:

\footnotetext{
${ }^{10}$ This assumption is made for tractability, since we are concerned with the first two moments. The argument is general and can be applied using the second-order approximation of any distribution where the moments are finite.
} 


$$
\frac{d \operatorname{Cov}\left(\alpha r_{D}, L\right)}{d \sigma_{r_{D}, L}}=\frac{E\left[\alpha(L) L^{2}\right]}{\sigma_{L}^{2}}>0,
$$

because the integrand in the expectation is non-negative (because $0 \leq \alpha \leq 1$ ). If the market for loan commitment is competitive, profits are eliminated (i.e $P_{L C}=0$ ), so that we have:

$$
\begin{aligned}
E\left[r_{L C}\right] & =\gamma\left[A-\operatorname{Cov}\left[\alpha r_{D}, L\right]\right] \\
A & \equiv \operatorname{Cov}\left[(1-\alpha) r_{U D}, L\right]+\operatorname{Cov}\left(\alpha r_{L}, L\right)
\end{aligned},
$$

and finally, we get the main result:

Proposition 1: The expected return decreases with an increasing covariance between funding costs and liquidity:

$$
\frac{d E\left[r_{L C}\right]}{d \sigma_{r_{D}, L}}=-\gamma \frac{d \operatorname{Cov}\left[\alpha r_{D}, L\right]}{d \sigma_{r_{D}, L}}<0 .
$$

Proposition 1 implies that only an intermediary with a high covariance between its funding cost and the availability of market liquidity (call it a "bank" for the moment) will be able to offer this product in equilibrium. Other intermediaries offering the product at prevailing prices would find the business unprofitable (negative NPV). Because these "non-bank" intermediaries experience more systematic risk when offering loan commitments, they would implicitly discount the expected returns at a higher rate than "banks." 
A finance company such as GE Capital is a real-world example of a "non-bank" intermediary. These intermediaries offer some similarities to banks on the asset side of their business because they lend (and lease) to borrowers with information problems. In fact, Carey, Post and Sharpe (1998) find no difference in measures of opacity for finance-company borrowers and bank borrowers, so they seem to solve the same kinds of information problems as banks. Most lines of credit, however, are issued by commercial banks rather than finance companies (Kashyap, Rajan and Stein, 2002). This difference makes sense in the context of our model because finance-company liabilities are composed mainly of commercial paper and bonds, thus their funding costs would tend to covary negatively with the availability of market liquidity, just the opposite of our theoretical "bank." In the next section, we will show that funding costs of real-world banks covary positively with market liquidity (i.e. $\sigma r_{D, L}>0$ ), whereas funding costs to finance companies do not.

By making one additional simplifying assumption, we can derive some cross-sectional implications from our model. Consider functions $\alpha(L)$ that are twice-differentiable such that

$$
E\left[\alpha^{\prime \prime}(L)\right] \geq 0
$$

Intuitively, since $\alpha$ is non-increasing, the first derivative is always non-positive, and since higher values for $-\alpha^{\prime}$ correspond to faster change in $\alpha$, writing the condition as $E\left[\left(-\alpha^{\prime}(L)\right)^{\prime}\right] \leq 0$ shows that the faster increase in draw-downs occurs, on average, for negative shocks $L$. In this way, the assumption rules out pathological cases but includes the desirable functional forms for $\alpha$.

Now, using the normality of $L$ we can write (see the Appendix A):

$$
\operatorname{Cov}\left(\alpha r_{D}, L\right)=\left(E\left[\alpha^{\prime \prime}(L)\right] \sigma_{L}^{2}+E[\alpha(L)]\right) \sigma_{r_{D} L}+E\left[r_{D}\right] E[\alpha(L) L]
$$


The positive slope is

$$
\frac{d \operatorname{Cov}\left[\alpha r_{D}, L\right]}{d \sigma_{r_{D}} L}=E\left[\alpha^{\prime \prime}(L)\right] \sigma_{L}^{2}+E[\alpha(L)]>0
$$

The last equation shows how the sensitivity of the loan commitment expected return to the covariance between the funding cost and the liquidity shocks depends on the particulars of borrower behavior, i.e. on the exact functional form for $\alpha$. We can illustrate this through some simple examples. First, we consider a constant function $\alpha$.

Case A: Constant withdrawals: $\alpha(L)=\alpha_{0}=\mathrm{E}(\alpha)$.

This function corresponds to the case of low-quality borrowers who draw their lines idiosyncratically (say, in response to a downgrade), regardless of the state of the economy (i.e. regardless of liquidity). In this case, we have:

$$
\frac{d E\left[r_{L C}\right]}{d \sigma_{r_{D}, L}}=-\gamma \alpha_{0} .
$$

Note that the intermediary with access to cheap funding still has a competitive advantage, which depends on both the price of liquidity risk and the expected frequency of loan takedowns.

Case B: Piecewise-linear withdrawals: $\alpha(L)=\left(L_{h i}-L\right) /\left(L_{h i}-L_{\text {low }}\right)$ for $L_{l o w} \leq L \leq L_{h i}<0$.

For this example, we assume that the commitments are always drawn $(\alpha=1)$ under a certain threshold level for the shock $\left(L<L_{\text {low }}\right)$, corresponding to the notion of "big" liquidity shocks, and always remain undrawn $(\alpha=0)$ if the shock $L$ is above a certain threshold level, $L>$ $L_{h i}>L_{\text {low }}$ (e.g. if the credit market is "good"). This simplification includes "natural" functional 
forms for $\alpha$, like gradual transition functions of the form:

$$
\left[\left(L_{h i}-L\right) /\left(L_{h i}-L_{\text {low }}\right)\right]^{a}, 0<a<1, \text { for } L_{\text {low }} \leq L \leq L_{h i}<0 .
$$

When $a=1$, the function becomes truncated linear, and we can also model a step function as the limiting case where $L_{\text {low }} \rightarrow L_{h}$. Since this function is not differentiable at $L_{h i}$ and $L_{l o w}$, we will show that the derivative is positive. We have (see the Appendix A)

$$
\frac{d E\left[r_{L C}\right]}{d \sigma_{r_{D}, L}}=-\frac{\gamma \sigma_{L}}{L_{h i}-L_{l o}}\left[\frac{L_{h i}}{\sigma_{L}} \Phi\left(\frac{L_{h i}}{\sigma_{L}}\right)-\frac{L_{l o}}{\sigma_{L}} \Phi\left(\frac{L_{l o}}{\sigma_{L}}\right)+2\left(\phi\left(\frac{L_{h i}}{\sigma_{L}}\right)-\phi\left(\frac{L_{l o}}{\sigma_{L}}\right)\right)\right],
$$

where $\Phi$ and $\phi$ are the normal cumulative distribution and density functions, respectively. At the limit $L_{\text {low }} \rightarrow L_{h i}, \alpha$ becomes the step function $\chi_{[-\infty, L h i]}$, that has value 1 on the interval $\left[-\infty, L_{h i}\right]$ and 0 otherwise, and in that case:

$$
\frac{d E\left[r_{L C}\right]}{d \sigma_{r_{D}, L}}=-\gamma\left[\Phi\left(\frac{L_{h i}}{\sigma_{L}}\right)-\frac{L_{h i}}{\sigma_{L}} \phi\left(\frac{L_{h i}}{\sigma_{L}}\right)\right],
$$

which can also be written as follows:

$$
\frac{d E\left[r_{L C}\right]}{d \sigma_{r_{D} L}}=-\gamma\left[\alpha_{0}\left(1-\frac{L_{h i}}{\sigma_{L}}\right)\right]
$$


Now, we can compare how the strength of the bank's funding hedge varies across two different sorts of borrowers: idiosyncratic borrowers and systematic borrowers. Idiosyncratic borrowers are those borrowers whose take-down behavior does not depend on liquidity (Case A); for example, high-risk borrowers whose behavior will depend mainly on changes in their own credit quality, independent of market conditions. Systematic borrowers, in contrast, are firms whose take-down behavior is predicated on the availability of market liquidity (Case B); for example, highly rated firms that would only draw funds in response to shocks to the supply of liquidity in the commercial paper market as a whole. If we consider two borrowers with the same expected take-down behavior (i.e. the same $\mathrm{E}(\alpha)=\alpha_{0}$ ), then equations (1) and (2) show that the borrower whose behavior is systematically related to market liquidity benefits more from access to bank-issued lines of credit, relative to the idiosyncratic borrower (assuming the these two borrowers draw on their lines with probability less than $1 / 2$; or, in the case of the idiosyncratic borrower, $L_{h i}<0$ ). Thus, banks, with their funding hedge, would be even more likely to dominate the market for lines of credit to high-grade firms whose take-down behavior is dominated by the systematic $L$-factor. In contrast, other financial institutions without access to bank-style funding (i.e. funding that flows in during periods of tight markets) might be better able to compete for lower-grade borrowers whose take-down behavior depends more on idiosyncratic credit shocks.

This cross-sectional implication of our model may help explain the empirical findings of Carey et al (1998), who show that finance-company borrowers are riskier than bank borrowers in observable ways (they have higher leverage), but not in ways suggesting that either banks or finance companies possess a comparative advantage in solving information problems. According to our model, they key difference has to do with liquidity risk. Banks have an especially large 
advantage among the class of borrowers where the main risk of making a loan commitment comes from liquidity risk - the risk of having to fund the loan when market spreads are high rather than default risk. When take-down behavior tends to be idiosyncratic, reflecting largely changes in a high-risk borrower's credit quality, the main risk of making a loan commitment stems from default; the liquidity advantage of banks for these borrower is less pronounced, thus helping to explain why finance companies tend to lend more to this kind of firm.

\section{EMPIRICAL EVIDENCE: BANKS' FUNDING ADVANTAGE IN OFFERING BACKUP LINES}

In this section, we test how the banking system responds to increases in the price of market-provided liquidity. We report aggregate time-series evidence that bank assets grow faster when the paper-bill spread is high than when it is low. This increased growth occurs not only in lending, but in banks' holdings of cash and securities as well. The increases in asset growth suggest that as demand for bank loans increases (in response to higher cost of borrowing in markets), so does the supply of funding (hence liquid assets rise rather than fall). [We also find that asset growth increases with spreads at all banks, whereas lending grows faster in response to tight spreads only at banks with high level of pre-existing loan commitments. See Appendix B.] We then look at the other side of the balance sheet, testing how banks' fund their increase in

growth. We find deposits overall, especially transactions deposits, grow faster as the paper-bill spread widens; other aspects of bank funding, however, do not grow faster when spreads widen. Third, we show that yields on large time deposits decrease with the spread, suggesting better funding availability to banks, whereas yields on finance company paper do not decrease. 


\section{Methods and Data}

The difficulty empirically with our tests is that shocks in the commercial paper market have historically been dramatic but brief. In Section II, we described instances in which commercial paper availability declined in response to market turmoil, such as the Penn Central default in the early 1970s. These spikes have occurred periodically over the past 25 years.

Figure 2 plots the paper-bill spread during our sample period, from 1988 to 2002. As the chart shows, the spikes in the spread tend to be dramatic but short-lived. For example, at the beginning of the U.S. air attack against Iraq in the middle of January of 1991, commercial paper spreads shot up above 100 basis points very briefly. Later, in the last week of September 1998, the Federal Reserve unexpectedly reduced its target for the Fed Funds rate in response to the LTCM debacle and rising concern of contagion. In response, commercial paper spreads rose from 68 basis points to 118 basis points in just two weeks. But by the beginning of November, the spreads had fallen back to 65 basis points.

Because of the way the markets have responded to events during our sample period, we think it is important to look at high-frequency data; with monthly or quarterly data one would run the risk of missing all of the interesting variation in the interest-rate spreads. We therefore explore how weekly banking data respond to the paper-bill spread. These data come from the Federal Reserve's H.8 statistical release. Although the H.8 data contain much less detail than, for example, data from the Reports of Income and Condition (the "Call Report”), they do offer the highest frequency look at banking system that is available. ${ }^{11}$ The weekly banking data are

\footnotetext{
${ }^{11}$ We use the data from the 50 weekly reporting banks, not seasonally adjusted, from 1988 to 2002 . These data come from the Federal Reserve Board's website, reflecting the activity of the 50 largest US banks.
} 
matched to interest rates on short-term government securities (3-months) and commercial paper rates. Our measure of market tightness, or the cost of market-provided liquidity, equals the spread between the 3-month commercial paper rate for highly rated (AA) non-financial borrowers and the 3-month T-Bill rate.

To test how market liquidity affects the banking system, we estimate a series of vector auto-regressions (VARs), each including three variables, one representing growth in the banking system and the other two reflecting interest rates (level and spreads). In particular, on the asset side we model the change in bank assets, the change in loans (total loans and C\&I loans), or the change in liquid assets (cash plus securities); on the liability side we model the change in deposits, the change in transactions deposits, the change in large time deposits and the change in non-transactions deposits. Each of these change variables is normalized by beginning-of-period assets.

We also report VARs with the change in the yield on large, negotiable certificates of deposit and with the change in the yield on short-term borrowing by finance companies. These results allow us to test how banks' cost of funds varies with market liquidity in comparison with their closest competitors. ${ }^{12}$ As the most direct comparison of funding costs for banks versus finance companies, we also test how the difference between the yield on large CDs and financecompany paper responds to market liquidity shocks.

The interest rate variables that we include in each VAR system are the change in shortterm interest rates (the three-month Treasury rate), and the spread between the commercial paper

\footnotetext{
${ }^{12} \mathrm{We}$ first difference all of the interest rate series because each has a very high degree of persistence. Differencing removes the possibility of generating spurious results stemming from the presence of a unit root.
} 
rate and this short-term interest rate. ${ }^{13}$ Summary statistics for the banking-system growth rates and the interest rate variables appear in Table 1.

Results

Table 2 summarizes the VAR results for growth in the banking system, Panel A for assetside growth and Panel B for liability-side growth. Table 3 then reports the VAR statistics for the models of bank and finance company funding costs. For each VAR, we also report the Impulse Response Function for a shock to the CP spread as a convenient way to understand the economic magnitude and timing of how liquidity shocks affect the banking system (Figure 3).

The first set of results (Table 2, Panel A) indicates that there is a substantial effect of the paper-bill spread on subsequent growth in the banking system. For example, the Grangercausality tests show that the paper-bill spread is useful in predicting subsequent bank asset growth, as well as growth in particular assets. The increased growth rates of both lending and liquid assets (cash+securities) strongly suggests that funding supply increases when market spreads widen; otherwise, banks would fund the increased demand for loans (by firms wanting to take down funds from $\mathrm{CP}$ backup lines) by running down their holdings of liquid assets.

To understand the magnitude of these effects, the impulse response of the asset growth rate suggests that an increase of 26 basis points (the difference between the $75^{\text {th }}$ and $25^{\text {th }}$ percentiles) in the paper-bill spread would be associated with an increase in asset growth of 0.40 percent in the following week. This asset growth increase is large relative to the median weekly growth rate in bank assets of 0.10 percent. For the growth of liquid assets, a 26 basis point rise

\footnotetext{
${ }^{13}$ We have also tried including a term structure variable equal to the difference in the yields on five-year Treasury Notes and the three-month Treasury Bill. Adding this variable has little effect on the results.
} 
in the spread is associated with an increase in the growth liquid assets of 0.17 percent.

The impulse responses also indicate little persistence in the effects of tightening spreads on lending. In the lending equations, the responses beyond one week are small: the second week response of loan growth to the 26 bp paper-bill rate increase is only about -0.004 percent. Overall, periods further out into the future have rapidly declining responses. Increases in market spreads only raise the growth rate of bank loans during the period of tight markets; once the market spreads decline, the growth rates quickly revert to their average levels. In the liquid asset growth equation, the subsequent impulse response effects are also negative but much larger, with a second week response of about -0.09 percent. This suggests that banks attempt to bring the level of liquid assets back to a target level very quickly following an unexpected increase or decrease due to change in market spreads. The declining responses mean that once the spread reverts to normal, liquid assets actually grow substantially more slowly than normal or even shrink thus allowing the banking system to return to the desired holdings of liquid assets rapidly.

In Panel B of Table 2, we test how bank funding changes with the paper-bill spread. These results suggest that the increase in asset growth is funded with additional deposits, particularly transaction deposits, consistent with our basic story of funding availability shifting from the capital markets to the banking system.

In Table 3, we estimate a VAR that includes the change in the yield on large, three-month negotiable certificates of deposit and the change in the Treasury Bill rate, along with the paperbill spread. In addition, we estimate a parallel VAR using the change in the three-month finance paper rate. The results provide further evidence that bank funding availability increases as the commercial paper spreads widen. Banks' reliance on transaction deposits increases with the 
paper-bill spread and, at the same time, the yield on large CDs declines. The coefficient suggest that a 26 basis point increase in the CP spread is followed by a decline in the bank CD rate of about six basis points. In contrast, funding costs for finance companies (such as GE Capital) actually increase slightly just after the shock. ${ }^{14}$ In the VAR with the difference between the CD rate and the finance company rate changes, we find declines in the first two weeks following the shock to the CP spread, after which time the spread change increases, bringing it back to its longrun level.

\section{Robustness}

Taken as a whole, our results so far suggest a shift in the willingness of investors to hold bank deposits, presumably perceived to be safe, relative to commercial paper (or financecompany paper), during periods of weak investor confidence. What explains the simultaneous widening of market spreads and funding flows into the banking system? Our view is that during periods of concern about market integrity (i.e. when spreads rise), the perceived value of the government safety net increases, as does the perceived likelihood of a bailout (or support of) the banking system. This idea seems particularly relevant to understanding the events following the Russian default and the fall of LTCM. [As further support for this safety net view, we show in the Appendix that increased funding following shocks to the $\mathrm{CP}$ spread are no greater at banks with high capital-asset ratios (safe banks) than at banks with low capital-asset ratios (risky banks)]. In addition, this notion can explain both increases in deposit funding (because concerned investor flee to banks) and declines in yields on uninsured deposits (because an

\footnotetext{
${ }^{14} \mathrm{We}$ know of no high-frequency data (e.g. weekly) on finance company, or other financial institution, balance sheets that would allow us to observe how their assets and funding sources respond to changes in the paper-bill spread. All pricing effects documented here are transitory, consistent with the notion of accommodating a supply shock.
} 
increased bailout probability reduces the risk of uninsured deposits). Of course, funding flows into the banking system can be directly facilitated by the central bank though its operation of monetary policy, either directly (with discount window lending) or with open market operations (to support increases in bank deposits). ${ }^{15}$ Increases in credit risk or, more generally, declines in market sentiment, could also play a role in explaining why investors might seek a safe haven for their funds.

Table 4 shows that our results are robust to variables that could potentially explain the funding supply shifting from the capital markets to the banking system having to do with changes in monetary policy, "transaction" liquidity (understood as availability of a willing counter-party), general credit risk, or "sentiment". We rule out alternatives empirically by testing whether our main findings are robust to including the following proxy variables: (1) for monetary policy, the growth in total reserves at the Fed; (2) as a measure of transaction liquidity, the on/off-the-run bill spread for the 30-year bond; (3) as a proxy for credit risk, the AAA-Baa bond spread; (4) as a measure of "sentiment", the implied volatility of the S\&P 100 from options prices (the VIX index).

The results show that the paper-bill spread continues to drive the results in the presence of these potentially omitted factors. The proxy variables are generally not useful in predicting the variables of interest. ${ }^{16}$ The exceptions are the on/off-the-run spread and the credit spread, which are both useful in predicting overall bank asset growth. Inclusion of these variables, however,

\footnotetext{
${ }^{15}$ Discount window lending by the Fed to commercial banks is almost never quantitatively significant throughout our sample period. The one exception is that the Fed did use the discount window to supply a significant quantity of liquidity during the days following the attack on the World Trade Center (McAndrews and Potter, 2003).

${ }^{16}$ The results (not reported here) also show that overall, the proxy variables are not useful in predicting the paper-bill spread.
} 
does not eliminate the importance of the paper-bill spread, nor does it change the shape or magnitude of the impulse response function.

\section{Empirical Evidence: Pricing of NeW Loan Commitments}

In this last section, we estimate how the pricing of new loan commitments responds to conditions in the commercial paper market. We have seen that when the paper-bill spread increases, funding availability increases so much that banks can actually increase their holding of liquid assets in the face of strong loan take-down demand. This result raises the possibility that the equilibrium price of new lines of credit may fall during periods of market tightness.

\section{Methods and Data}

To test this idea, we use the Dealscan database, compiled by the Loan Pricing Corporation (LPC). LPC is a private firm that collects up-to-date information on lending for its institutional clients. LPC also maintains a historical database, Dealscan, that contains information on the pricing and non-price terms of a large number of loans made over the past 10 years. The historical data in Dealscan come primarily from SEC filings, although LPC also receives data from large loan syndicators as well as from a staff of reporters. According to LPC, most loans made to large publicly traded companies (e.g. the Forbes 500) appear in Dealscan. There is very little information, however, on lending to small and middle-market firms (see Strahan, 1999), although this non-random selection of firms poses little trouble for our study because we will focus only on commercial paper borrowers.

Dealscan provides detailed information on bank loans to large corporations from 1988 to the present. Coverage in the database is sparse during the late 1980s, however, so we begin our 
sample in 1991. The Dealscan data have both price and non-price terms of loans at origination, along with information on borrower rating and borrower sales, but there is no information about pricing in the secondary market. ${ }^{17}$ The pricing terms include both the "drawn all-in spread", which equals the annual cost to a borrower for drawn funds, inclusive of all fees. The drawn spread is defined as a markup over LIBOR. Dealscan also contains the "undrawn spread", equal to the annual fees that the borrower must pay its bank for funds committed under the line but not taken down. $^{18}$

In addition to the two pricing variables, Dealscan includes limited information on the borrower, allowing us to control for borrower risk with a set of Moody's senior-debt ratings indicators, and for borrower size by including the log of sales during the year prior to loan origination. We match the Dealscan data to three daily interest rate variables, the yield on the three-month Treasury Bill, a term structure variable equal to the difference between the yield on the five-year Treasury Note and the three-month Bill, and the paper-bill spread. The coefficient on the paper-bill spread allows us to test whether the price of new $\mathrm{CP}$ backup lines declines when the price of market-provided liquidity increases, as suggested by the strong funding availability to banks.

Beside the three interest rates and the variables controlling for borrower attributes, we also control for the non-price terms of the lines by including the log of the commitment amount, the log of maturity, and a secured indicator variable. Because these terms may be jointly

\footnotetext{
${ }^{17}$ For information on loan trading in the secondary market, see Carey and Bhasin (1999).

${ }^{18}$ LPC's use of the word "spread" when referring to fees on undrawn commitments is puzzling because these fees are not markups over market interest rates.
} 
determined with the prices, we estimate our models both with and without these variables. Finally, we introduce a log-linear trend variable into some specifications to rule out the possibility that common trends in interest rates can explain the results. ${ }^{19}$

We build our sample from the set of all commercial paper backup lines of credit on Dealscan originated between January 1, 1991 and the end of first quarter of 2002, for a total of 2,695 commitments. Of these, Dealscan contains information on the drawn spread for 2,155 commitments, and information on the undrawn fees for 1,882 commitments. Borrower sales is also missing for some of these loans, so our regression samples include between 1,520 and 1,720 observations. Also, because we sometimes have multiple observations on a single day, we report standard errors that account for possible correlation in the error across loans made on the same day.

Table 5 reports the summary statistics for all of the variables in the models. The average drawn spread over LIBOR equals about 61 basis points (compared to a mean paper-bill spread of 30 basis points), and the average undrawn spread equals about 13 basis points. Most of the lines are secured ( 84 percent), and their average maturity equals 18 months. The backup lines tend to be large, with a mean commitment amount of \$635 million, reflecting the large size of the typical commercial paper issuer (average sales size equals $\$ 8.6$ billion). More that half of the borrowers have an S\&P senior debt rating, although 43 percent of the borrowers do not have a rating.

\section{Results}

Tables 6 and 7 report the results from the loan pricing regressions. In Table 6, we omit

\footnotetext{
${ }^{19}$ Note that we can not use standard time series techniques because we do not have lagged values of the variables; each loan is made only once, and the loans are not homogeneous.
} 
the non-price term variables from the regressions (log of commitment amount, log of maturity and the secured indicator), while the specifications in Table 7 include these variables. Also, for each table we include two panels. Panel A reports the results with all of the available observations, including the 43 percent of borrowers without a debt rating and thus no way to control for borrower risk; in these regressions, we include an indicator equal to one for the unrated borrowers. Panel B reports the results with only the set of borrowers with a Moody's rating. We also report two specifications in each panel, one that includes a log-linear time trend, and one without this variable. There are 16 specifications in all.

Before turning to the interest rate results, notice that the other variables enter the regressions with sensible coefficients. Larger borrowers, for example, pay lower drawn and undrawn spreads on their lines of credit. Also, the coefficients on the ratings indicators, which we do not report in the tables, suggest that higher-rated firms pay lower spreads than lower-rated firms. For example, a borrower rated Aa or better would pay, on average, about 8 basis points less for undrawn funds than a borrower rated below Baa and about 50 basis points less for funds drawn off of these lines.

The coefficients on the non-price terms suggest that larger loans come with lower spreads; longer term loans have higher undrawn spreads but lower drawn spreads; and, secured loans come with higher spreads than unsecured loans. These last three results, however, are especially hard to interpret because the price and non-price terms are jointly determined. So, for example, risky firms tend to pay high interest rates for funds and their loans tend to be secured, explaining the positive coefficient on the secured indicator even though the identical loan secured 
would be safer than if it were not secured. ${ }^{20}$

Looking now at the interest rate coefficients, in all 16 specifications in the two tables (eight for the drawn spread and eight for the undrawn spread), we find a statistically significant, negative relationship between the market price of liquidity (the paper-bill spread) and the price charged for liquidity insurance by banks. The result is robust across several dimensions. First, the coefficient on the paper-bill spread does not change appreciably when we add the non-price terms to the model; second, this coefficient does not change when we control for time trends; third, it does not change when we drop the un-rated firms. Moreover, the paper-bill spread is the only interest rate variable with a consistent impact on the pricing of these lines of credit. The other interest rate variables - the short-term interest rate and the term structure spread - do not have a consistent impact on either the drawn or the undrawn spread. (The coefficient on the term structure variable becomes indistinguishable from zero when we control for the time trend.)

The coefficient on the paper-bill spread is not only statistically significant, but it is economically significant as well. For example, a one standard deviation increase in the paper-bill spread ( 20 basis points) is associated with an decrease in the drawn spread of about 3.2 basis points, or about 5 percent of the unconditional mean (60 basis points). A 20 basis point increase in the paper-bill spread comes with a decline of about 0.5 basis points in the undrawn spread, again about 5 percent of the unconditional mean (13 basis points).

While we have shown that the price of new commercial paper backup lines of credit declines with market spreads, even controlling for the non-price terms of the loans, Table 8 explores how these non-price terms themselves co-vary with the paper-bill spread. The results

\footnotetext{
${ }^{20}$ See Berger and Udell (1990) for evidence that secured borrowers are riskier than unsecured borrowers.
} 
suggest no effect of spreads on either the commitment size or the likelihood that a loan commitment is secured. We do find, however, that the maturity of the backup lines declines with the paper-bill spread. According to the coefficients, a 20 basis point increase in the spread is associated with a decline in average maturity of about four percent (the dependent variables is in logs). So, banks offer new lines of credit more cheaply during periods of wide spreads, we argue, because of the inflow of funds. This last result on maturity suggests, however, that these new lines tend to be somewhat shorter lived than average, perhaps because banks anticipate that the strong funding availability is temporary.

\section{Conclusions}

We have shown why banks are well suited to providing liquidity insurance to large borrowers. During periods when commercial paper spreads widen - periods when borrowing in the markets is expensive - banks are flush with funds. As evidence, we document that both loans and liquid assets grow faster at banks when the paper-bill spread widens and, at the same time, yields on large CDs fall. Borrowers are also more apt to take funds down from pre-existing lines of credit established during these tight times. Thus, because the funding is there when it is needed, banks can offer this liquidity insurance without having to carry a large bucket of liquid assets - assets that are costly to hold both because they earn low returns and because they exacerbate managerial agency problems. The funding inflows are not only useful in helping banks meet their obligations to customers when liquidity demands are high, but they are also large enough to allow banks to make new loan commitments at lower-than-average prices.

In our view, arguments about "bank specialness" must have something to do with a link 
or "synergy" between the funding and lending sides of the business. Otherwise, the specialness has to do with intermediation generally rather than with banking. Our results find such a link. Because banks are viewed as a safe haven for funds, during periods of market uncertainty both the supply of bank funds and the demand for bank loans tend to move up together. We do not find, however, that finance companies experience better funding supply during these periods of tight markets. In our view, funding flows into the banking system during periods of high spreads because implicit and explicit government support of banks enhances investors' willingness to hold deposits. An increased level of (implicit) support during crises is consistent not only with greater funding flows, but also with lower yields on large deposits that are not explicitly insured by the government. It is difficult to know, however, whether similar funding flows could occur in the absence of government safety nets. We simply have not lived in such a world for a long time. An interesting extension of this research would be to study the time-series response of the banking system to market shocks before and after the establishment of the FDIC in 1933. 


\section{References}

Berger, Allen N. and Gregory F. Udell, 1992, "Some Evidence on the Empirical Significance of Credit Rationing," Journal of Political Economy.

Berger, Allen N. and Gregory F. Udell, 1990, "Collateral, Loan Quality and Bank Risk," Journal of Monetary Economics.

Boyd, John and Mark Gertler, 1994, “Are Banks Dead? Or, Are the Reports Greatly Exagerrated?" Federal Reserve Bank of Minneapolis, Quarterly Review (Summer 1994), 1-19.

Boot, Arnaud, Anjan Thakor and Gregory Udell, 1987, "Competition, Risk Neutrality and Loan Commitments," Journal of Banking and Finance 11, 449-471.

Calomiris, Charles W. and Charles M. Kahn, 1991, "The Role of Demandable Debt in Structuring Optimal Banking Arrangements, American Economic Review 81(3), 497-513.

Carey, Mark S., and Vijay Bhasin, 1999, "The Determinants of Corporate Loan Liquidity," Federal Reserve Bank of Chicago, Proceedings of the 35th Conference on Bank Structure and Competition.

Carey, Mark S., Mitch Post, and Steven Sharpe, 1998, "Does Corporate Lending by Banks and Finance Companies Differ? Evidence on Specialization in Private Debt Contracting, Journal of Finance, 53.

Chava, Sudheer, 2002, "Modeling Loan Commitments and Liquidity Crisis: Theory and Estimation," mimeo, November 19, 2002.

Covitz, Daniel and Chris Downing, 2002, "Insolvency or Liquidity Squeeze? Explaining Short-Term Corporate Yield Spreads," Finance and Economics Discussion Series 2002-45, Washington: Board of Governors of the Federal Reserve System.

Diamond, Douglas and Ragurham G. Rajan, 2001, "Liquidity Risk, Liquidity Creation and Financial Fragility: A Theory of Banking," Journal of Political Economy 109(2), 287-327.

Fama, Eugene, 1985, “What's Different about Banks?” Journal of Monetary Economics (January).

Flannery, Mark, 1994, "Debt Maturity Structure and the Debtweight Cost of Leverage: Optimally Financing Banking Firms," American Economic Review (March), 320-331.

Froot, Kenneth A., and Jeremy C. Stein, 1998, "Risk Management, Capital Budgeting, and Capital Structure Policy for Financial Institutions: An Integrated Approach," Journal of 
Financial Economics, 47, 55-82.

Kanatas, George, 1987, "Commercial Paper, Bank Reserve Requirements and the Informational Role of Loan Commitments," Journal of Banking and Finance 11, 425-448.

Kane, Edward, 1974, “All for the Best: The Federal Reserve Board's $60^{\text {th }}$ Annual Report," American Economic Review, December, 835-850.

Kashyap, Anil K, Raghuram G. Rajan and Jeremy C. Stein, 2002, "Banks as Liquidity Providers: An Explanation for the Co-existence of Lending and Deposit-Taking," Journal of Finance 57(1), 33-74.

Krishnamurthy, Arvind, 2001, “The Bond/Old Bond Spread,” mimeo, June 13, 2001.

McAndrews, James J. and Simon M. Potter, 2002, "Liquidity Effects Surrounding the Events of September 11, 2001," Federal Reserve Bank of New York Economic Policy Review, November 2002.

Mishkin, Frederic and Philip E. Strahan, "What will Technology do to Financial Structure?" 1998, in The Effect of Technology on the Financial Sector, Brookings-Wharton Papers on Financial Services, edited by Robert Litan and Anthony Santomero, 249-87.

Mester, Loretta J., and Mitchell Berlin, 1999, "Deposits and Lending Relationships," Review of Financial Studies 12, 579-608.

Mester, Loretta J., Leonard Nakamura and Micheline Renault, 2002, "Checking Accounts and Bank Monitoring," Federal Reserve Bank of Philadelphia WP no. 01-3/R.

Morgan, Donald P., 1998, "The Credit Effects of Monetary Policy: Evidence Using Loan Commitments," Journal of Money, Credit and Banking.

Myers, Stewart C. and Raghuram G. Rajan, 1998, “The Paradox of Liquidity,” Quarterly Journal of Economics 113, 733-71.

Saidenberg, Marc R. and Philip E. Strahan, 1999, “Are Banks Still Important for Financing Large Businesses?" 1999, Federal Reserve Bank of New York's Current Issues in Economics and Finance 5(12), 1-6.

Shockley, Richard and Anjan Thakor, 1997, "Bank Loan Commitments: Data, Theory, Tests," Journal of Money, Credit and Banking 29.

Stiglitz, Joseph and Andrew Weiss 1981, "Credit Rationing in Markets with Imperfect Information" American Economic Review 71, (3), 393-410. 
Strahan, Philip E., 1999, "Borrower Risk and the Price and Non-Price Terms of Bank Loans," Federal Reserve Bank of New York, Staff Report no. 90.

Thakor, Anjan, and Gregory Udell, 1987, "An Economic Rationale for the Pricing Structure of Bank Loan Commitments," Journal of Banking and Finance 11, 271-289. 


\section{Table 1 \\ Summary Statistics for Weekly U.S. Banking-System Growth Rates}

This table reports summary statistics for weekly growth rates in bank assets, deposits, loans and liquid assets (cash+securities). The sample is based on the aggregation of large U.S. banks that report weekly, from the Federal Reserve's H.8 statistical release, 1988 to 2002. Also reported is the paper-bill spread, defined as the 3month commercial paper rate for highly rated borrowers minus the 3-month Treasury Bill rate, the 3-month Treasury Bill rate, and the rates on large bank CDs and finance-company paper. Interest rate data are from the Federal Reserve Board of Governors. All measured in percentage points

\begin{tabular}{|c|c|c|c|}
\hline & $\begin{array}{c}25^{\text {th }} \\
\text { Percentile }\end{array}$ & Median & $\begin{array}{c}75^{\text {th }} \\
\text { Percentile }\end{array}$ \\
\hline$\Delta$ Assets / Assets $_{\mathrm{t}-1}$ & -0.73 & 0.10 & 0.87 \\
\hline 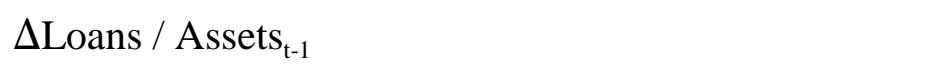 & -0.16 & 0.02 & 0.24 \\
\hline$\Delta \mathrm{C} \& \mathrm{I}$ Loans / Assets $_{\mathrm{t}-1}$ & -0.06 & -0.004 & 0.07 \\
\hline$\Delta$ Liquid assets (Cash+Securities) / Assets $_{t-1}$ & -0.43 & 0.01 & 0.53 \\
\hline 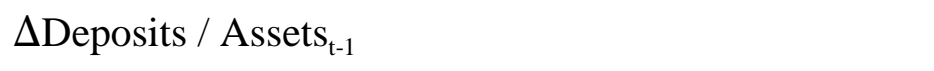 & -0.77 & -0.05 & 0.94 \\
\hline 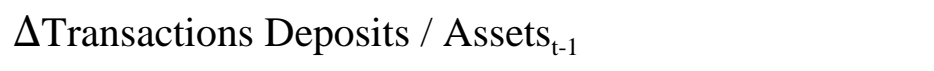 & -0.68 & 0.02 & 0.67 \\
\hline$\Delta$ Non-Transactions / Assets $_{\mathrm{t}-1}$ & -0.25 & -0.04 & 0.18 \\
\hline$\Delta$ Large Time Deposits / Assets $_{\mathrm{t}-1}$ & -0.06 & -0.005 & 0.05 \\
\hline$\Delta$ Annual Yield on 3-Month Treasury Bill & -0.06 & 0 & 0.05 \\
\hline$\Delta$ Annual Yield on 3-Month Rate on Negotiable CDs & -0.04 & 0 & 0.03 \\
\hline$\Delta$ Annual Yield on 3-Month Rate on Finance Paper & -0.03 & 0 & 0.04 \\
\hline$\Delta$ (Yield on Negotiable CDs - Yield on Finance Paper) & -0.02 & 0 & 0.02 \\
\hline Paper - Bill Spread & 0.18 & 0.29 & 0.44 \\
\hline
\end{tabular}




\title{
Table 2
}

\section{Vector Auto-Regressions of Weekly U.S. Banking System Growth Rates on the Paper-Bill Spread and Interest Rates}

\author{
Panel A: Asset Growth
}

\begin{abstract}
Granger causality Wald tests and impulse response functions for VARs with three equations. There is one equation for the asset variable. The other two equations are for the paper-bill spread and the change in the three month Treasury Bill rate. Each VAR is estimated with four lags. We report the $\chi^{2}$ statistic testing the null that all of the coefficients equal zero. For each VAR, we also report a corresponding impulse response function to quantify the impact of a standard-deviation innovation in the paper-bill spread on the growth in bank balance sheets. The sample is based on weekly data over the 1988 to 2002 period, from the Federal Reserve Board's H. 8 statistical release. See Table 1 for summary statistics.
\end{abstract}

Granger causality Wald tests

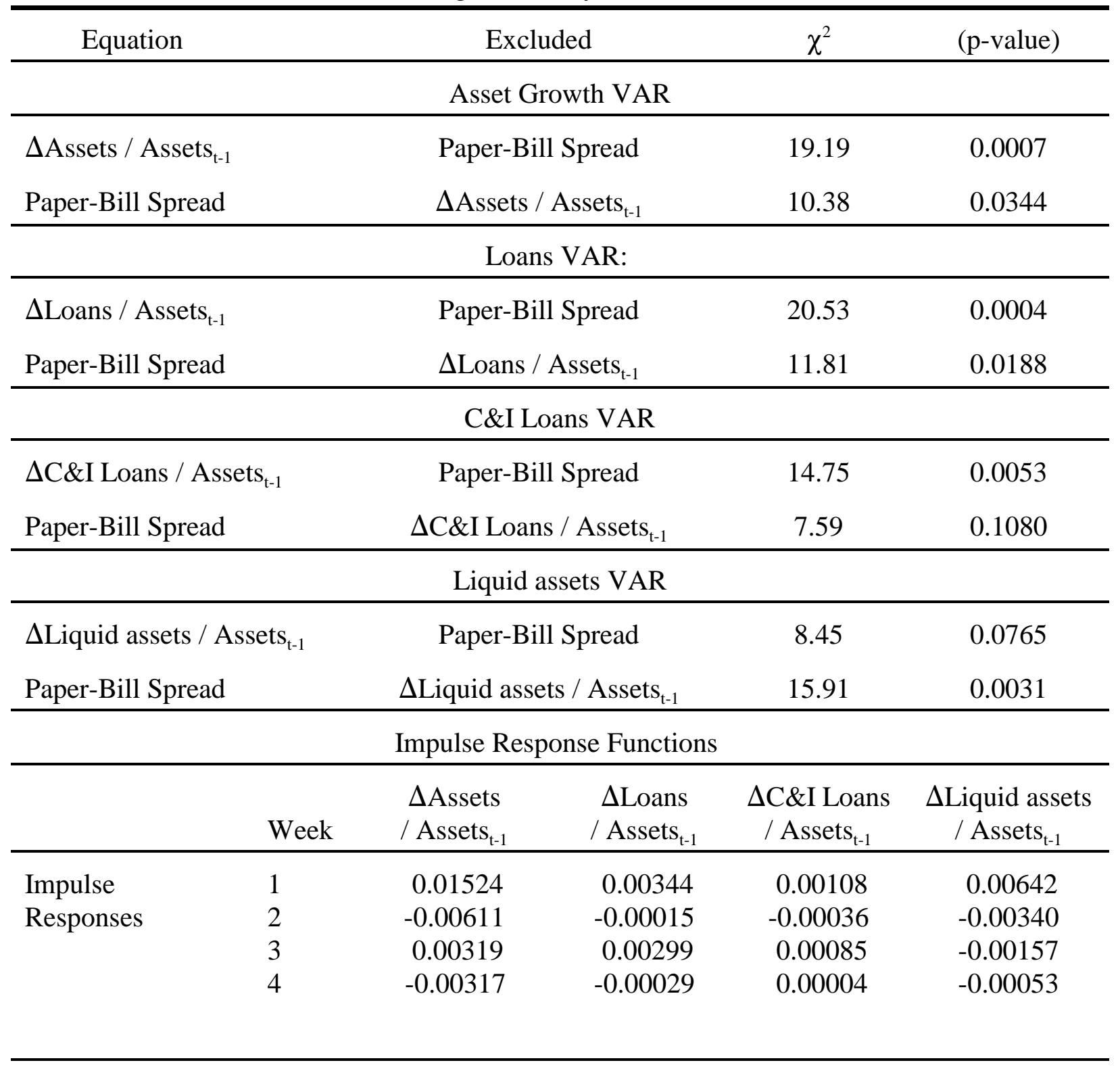




\title{
Table 2
}

\section{Vector Auto-Regressions of Weekly U.S. Banking System Growth Rates on the Paper-Bill Spread and Interest Rates}

Panel B: Liability Growth

\begin{abstract}
Granger causality Wald tests and impulse response functions for VARs with three equations. There is one equation for the asset variable. The other two equations are for the paper-bill spread and the change in the three month Treasury Bill rate. Each VAR is estimated with four lags. We report the $\chi^{2}$ statistic testing the null that all of the coefficients equal zero. For each VAR, we also report a corresponding impulse response function to quantify the impact of a standard-deviation innovation in the paper-bill spread on the growth in bank balance sheets. The sample is based on weekly data over the 1988 to 2002 period, from the Federal Reserve Board's H. 8 statistical release. See Table 1 for summary statistics.
\end{abstract}

Granger causality Wald tests

\begin{tabular}{|c|c|c|c|c|}
\hline Equation & \multicolumn{2}{|c|}{ Excluded } & $\chi^{2}$ & (p-value) \\
\hline \multicolumn{5}{|c|}{ Deposits VAR } \\
\hline$\Delta{\text { Deposits } / \text { Assets }_{\mathrm{t}-1}}$ & \multicolumn{2}{|c|}{ Paper-Bill Spread } & 22.87 & 0.0001 \\
\hline Paper-Bill Spread & \multicolumn{2}{|c|}{$\Delta$ Deposits / Assets $_{\mathrm{t}-1}$} & 15.84 & 0.0032 \\
\hline \multicolumn{5}{|c|}{ Transaction Deposits VAR: } \\
\hline$\Delta{\text { Transact Dep } / \text { Assets }_{\mathrm{t}-1}}$ & \multicolumn{2}{|c|}{ Paper-Bill Spread } & 24.68 & 0.0001 \\
\hline Paper-Bill Spread & \multicolumn{2}{|c|}{$\Delta$ Transact Dep / $^{\text {Assets }}$ t-1 } & 13.82 & 0.0079 \\
\hline \multicolumn{5}{|c|}{ Non-Transaction Deposits VAR } \\
\hline 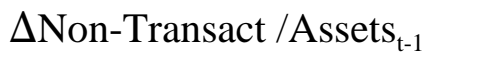 & \multicolumn{2}{|c|}{ Paper-Bill Spread } & 8.45 & 0.0765 \\
\hline Paper-Bill Spread & \multicolumn{2}{|c|}{ 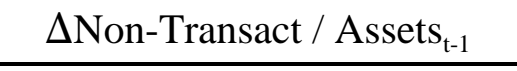 } & 5.25 & 0.2628 \\
\hline \multicolumn{5}{|c|}{ Large Time Deposits VAR } \\
\hline$\Delta$ Large Time Dep /Assets ${ }_{\mathrm{t}-1}$ & \multicolumn{2}{|c|}{ Paper-Bill Spread } & 16.96 & 0.0020 \\
\hline Paper-Bill Spread & \multicolumn{2}{|c|}{ 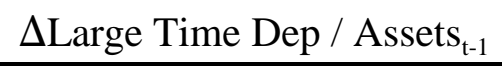 } & 1.39 & 0.8456 \\
\hline \multicolumn{5}{|c|}{ Impulse Response Functions } \\
\hline Week & $\begin{array}{c}\Delta \text { Deposits } \\
\text { Assets }_{\mathrm{t}-1} \\
\end{array}$ & $\begin{array}{c}\Delta \text { Transact } \\
\text { Dep/Assets }_{\mathrm{t}-1}\end{array}$ & $\begin{array}{c}\Delta \text { Non-Transact/ } \\
\text { Assets }_{\mathrm{t}-1}\end{array}$ & $\begin{array}{l}\Delta \text { Large Time } \\
\text { Dep/Assets }_{\mathrm{t}-1}\end{array}$ \\
\hline Impulse & 0.01396 & 0.01388 & 0.00077 & 0.00056 \\
\hline Responses & -0.00261 & -0.00392 & 0.00065 & 0.00085 \\
\hline 3 & 0.00151 & -0.00154 & 0.00254 & 0.00098 \\
\hline 4 & -0.00735 & -0.00431 & -0.00073 & 0.00025 \\
\hline
\end{tabular}




\section{Table 3}

Vector Auto-Regressions of Weekly Changes in Bank and Finance Company Marginal Funding Cost on the Paper-Bill Spread and Interest Rates

\footnotetext{
Granger causality Wald tests and impulse response functions for VARs with three equations. There is one equation for the asset variable. The other two equations are for the paper-bill spread and the change in the three month Treasury Bill rate. Each VAR is estimated with four lags. We report the $\chi^{2}$ statistic testing the null that all of the coefficients equal zero. For each VAR, we also report a corresponding impulse response function to quantify the impact of a standard-deviation innovation in the paper-bill spread on the growth in bank balance sheets. The sample is based on weekly data over the 1988 to 2002 period, from the Federal Reserve Board's H. 8 statistical release. See Table 1 for summary statistics.
}

Granger causality Wald tests

\begin{tabular}{|c|c|c|c|c|c|}
\hline \multicolumn{2}{|c|}{ Equation } & \multicolumn{2}{|c|}{ Excluded } & $\chi^{2}$ & (p-value) \\
\hline \multicolumn{6}{|c|}{ Deposits VAR } \\
\hline \multicolumn{2}{|c|}{$\Delta$ Yield on Large CDs } & \multicolumn{2}{|c|}{ Paper-Bill Spread } & 12.75 & 0.0125 \\
\hline \multicolumn{2}{|c|}{ Paper-Bill Spread } & \multicolumn{2}{|c|}{$\Delta$ Yield on Large CDs } & 57.65 & 0.0000 \\
\hline \multicolumn{6}{|c|}{ Transaction Deposits VAR: } \\
\hline \multicolumn{2}{|c|}{$\begin{array}{l}\Delta \text { Yield on Finance } \\
\text { Company Paper }\end{array}$} & \multicolumn{2}{|c|}{ Paper-Bill Spread } & 13.23 & 0.0102 \\
\hline \multicolumn{2}{|c|}{ Paper-Bill Spread } & \multicolumn{2}{|c|}{$\begin{array}{c}\Delta \text { Yield on Finance } \\
\text { Company Paper }\end{array}$} & 14.57 & 0.0057 \\
\hline \multicolumn{6}{|c|}{ Non-Transaction Deposits VAR } \\
\hline \multicolumn{2}{|c|}{$\begin{array}{l}\text { Yield on Large CDs - } \\
\text { Yield on Finance Paper }\end{array}$} & \multicolumn{2}{|c|}{ Paper-Bill Spread } & 15.75 & 0.0034 \\
\hline \multicolumn{2}{|c|}{ Paper-Bill Spread } & \multicolumn{2}{|c|}{$\begin{array}{l}\text { Yield on Large CDs - } \\
\text { Yield on Finance Paper }\end{array}$} & 15.96 & 0.0031 \\
\hline \multicolumn{6}{|c|}{ Impulse Response Functions } \\
\hline & Week & $\begin{array}{l}\Delta \text { Yield on } \\
\text { Large CDs }\end{array}$ & $\begin{array}{l}\Delta \text { Yield on Finance } \\
\text { Company Paper }\end{array}$ & \multicolumn{2}{|c|}{$\begin{array}{l}\text { Yield on Large CDs - } \\
\text { Yield on Finance Paper }\end{array}$} \\
\hline Impulse & 1 & -0.23776 & 0.09730 & \multicolumn{2}{|c|}{-0.01006} \\
\hline \multirow[t]{3}{*}{ Responses } & 2 & -0.08887 & -0.06112 & \multicolumn{2}{|c|}{-0.09286} \\
\hline & 3 & 0.19436 & 0.15753 & \multicolumn{2}{|c|}{0.08751} \\
\hline & 4 & -0.09037 & -0.06648 & \multicolumn{2}{|c|}{-0.02617} \\
\hline
\end{tabular}




\title{
Table 4 \\ Robustness Tests for Omitted Variables \\ Panel A: Asset Growth and Liability Growth
}

\begin{abstract}
Granger causality Wald tests for VARs with four equations. Equation one is for one of the following potentially omitted variables: 1. the growth in bank reserves; 2. the on-the-run/off-the-run spread for 30 years Treasuries; 3 . the implied volatility for the S\&P 100; 4. the spread between AAA and Baa corporate bonds. There is one equation for the asset or liability variable. The other two equations are for the paper-bill spread and the change in the three month Treasury Bill rate. Each VAR is estimated with four lags. We report the $\chi^{2}$ statistic and p-value testing the null that all of the coefficients equal zero. The sample is based on weekly data over the 1988 to 2002 period, from the Federal Reserve Board's H.8 statistical release. See Table 1 for summary statistics.
\end{abstract}

\begin{tabular}{|c|c|c|c|c|}
\hline \multirow[b]{2}{*}{$\begin{array}{l}\text { Potentially Omitted } \\
\text { Variable (top row): }\end{array}$} & \multicolumn{4}{|c|}{ Equation } \\
\hline & $\begin{array}{l}\Delta \text { Assets / }^{\text {Assets }}{ }_{\mathrm{t}-1} \\
\end{array}$ & $\begin{array}{l}\Delta \text { Loans }^{\prime} \\
\text { Assets }_{\mathrm{t}-1}\end{array}$ & $\begin{array}{l}\Delta \text { Deposits } \\
\text { /Assets }_{\mathrm{t}-1}\end{array}$ & $\begin{array}{c}\Delta \text { Transact Dep }^{\text {/Assets }} \text { t-1 } \\
\end{array}$ \\
\hline $\begin{array}{l}\text { Growth in Bank } \\
\text { Reserves }\end{array}$ & $\begin{array}{c}5.79 \\
(0.2154)\end{array}$ & $\begin{array}{c}6.90 \\
(0.1411)\end{array}$ & $\begin{array}{c}3.38 \\
(0.4963)\end{array}$ & $\begin{array}{c}10.91 \\
(0.0275)\end{array}$ \\
\hline Paper-Bill Spread & $\begin{array}{c}18.03 \\
(0.0012)\end{array}$ & $\begin{array}{c}20.27 \\
(0.0004)\end{array}$ & $\begin{array}{c}22.32 \\
(0.0002)\end{array}$ & $\begin{array}{l}23.3645 \\
(0.0001)\end{array}$ \\
\hline $\begin{array}{l}\text { On-the-run / Off-the- } \\
\text { run Spread }\end{array}$ & $\begin{array}{c}14.96 \\
(0.0048)\end{array}$ & $\begin{array}{c}4.23 \\
(0.3763)\end{array}$ & $\begin{array}{c}6.54 \\
(0.1626)\end{array}$ & $\begin{array}{c}10.03 \\
(0.0399)\end{array}$ \\
\hline Paper-Bill Spread & $\begin{array}{c}15.11 \\
(0.0045)\end{array}$ & $\begin{array}{c}19.26 \\
(0.0007)\end{array}$ & $\begin{array}{c}18.22 \\
(0.0011)\end{array}$ & $\begin{array}{c}26.08 \\
(0.0000)\end{array}$ \\
\hline $\begin{array}{l}\text { Implied Volatility on } \\
\text { S\&P } 100\end{array}$ & $\begin{array}{l}3.8763 \\
(0.4230)\end{array}$ & $\begin{array}{c}4.62 \\
(0.3282)\end{array}$ & $\begin{array}{c}6.78 \\
(0.1481)\end{array}$ & $\begin{array}{c}4.31 \\
(0.3659)\end{array}$ \\
\hline Paper-Bill Spread & $\begin{array}{l}19.26 \\
(0.0007)\end{array}$ & $\begin{array}{c}19.71 \\
(0.0006)\end{array}$ & $\begin{array}{c}24.91 \\
(0.0001)\end{array}$ & $\begin{array}{c}27.95 \\
(0.0000)\end{array}$ \\
\hline $\begin{array}{l}\text { Yield Spread AAA- } \\
\text { Baa Corporate Bonds }\end{array}$ & $\begin{array}{c}14.49 \\
(0.0059)\end{array}$ & $\begin{array}{c}26.50 \\
(0.0000)\end{array}$ & $\begin{array}{c}2.93 \\
(0.5698)\end{array}$ & $\begin{array}{c}3.03 \\
(0.5534)\end{array}$ \\
\hline Paper-Bill Spread & $\begin{array}{c}21.54 \\
(0.0002)\end{array}$ & $\begin{array}{c}33.05 \\
(0.0000)\end{array}$ & $\begin{array}{c}21.43 \\
(0.0003)\end{array}$ & $\begin{array}{c}22.96 \\
(0.0001)\end{array}$ \\
\hline
\end{tabular}




\section{Table 4}

\section{Robustness Tests for Omitted Variables}

\section{Panel B: Bank and Finance Company Marginal Funding Cost}

Granger causality Wald tests for VARs with four equations. Equation one is for one of the following potentially omitted variables: 1 . the growth in bank reserves; 2. the on-the-run/off-the-run spread for 30 years Treasuries; 3 . the implied volatility for the S\&P 500; 4. the spread between AAA and Baa corporate bonds. There is one equation for the funding cost variable. The other two equations are for the paper-bill spread and the change in the three month Treasury Bill rate. Each VAR is estimated with four lags. We report the $\chi^{2}$ statistic and p-value testing the null that all of the coefficients equal zero. The sample is based on weekly data over the 1988 to 2002 period, from the Federal Reserve Board's H.8 statistical release. See Table 1 for summary statistics.

Equation

\begin{tabular}{|c|c|c|c|}
\hline $\begin{array}{l}\text { Potentially Omitted } \\
\text { Variable (top row): }\end{array}$ & $\begin{array}{c}\text { Yield on Large } \\
\text { CDs }\end{array}$ & $\begin{array}{c}\text { Yield on Finance } \\
\text { Paper }\end{array}$ & $\begin{array}{l}\text { Yield Large CD - } \\
\text { Yield on Finance Paper }\end{array}$ \\
\hline $\begin{array}{l}\text { Growth in Bank } \\
\text { Reserves }\end{array}$ & $\begin{array}{c}1.69 \\
(0.7926)\end{array}$ & $\begin{array}{c}3.89 \\
(0.4206)\end{array}$ & $\begin{array}{c}3.81 \\
(0.4317)\end{array}$ \\
\hline Paper-Bill Spread & $\begin{array}{c}11.79 \\
(0.0190)\end{array}$ & $\begin{array}{c}13.91 \\
(0.0076)\end{array}$ & $\begin{array}{c}16.03 \\
(0.0030)\end{array}$ \\
\hline $\begin{array}{l}\text { On-the-run / Off-the- } \\
\text { run Spread }\end{array}$ & $\begin{array}{c}5.44 \\
(0.2453)\end{array}$ & $\begin{array}{c}6.20 \\
(0.1845)\end{array}$ & $\begin{array}{c}3.79 \\
(0.4354)\end{array}$ \\
\hline Paper-Bill Spread & $\begin{array}{c}20.43 \\
(0.0004)\end{array}$ & $\begin{array}{c}23.12 \\
(0.0001)\end{array}$ & $\begin{array}{c}14.40 \\
(0.0061)\end{array}$ \\
\hline $\begin{array}{l}\text { Implied Volatility on } \\
\text { S\&P } 100\end{array}$ & $\begin{array}{c}3.81 \\
(0.4320)\end{array}$ & $\begin{array}{c}7.46 \\
(0.1137)\end{array}$ & $\begin{array}{c}1.73 \\
(0.7859)\end{array}$ \\
\hline Paper-Bill Spread & $\begin{array}{c}11.44 \\
(0.0220)\end{array}$ & $\begin{array}{c}12.30 \\
(0.0153)\end{array}$ & $\begin{array}{c}16.18 \\
(0.0028)\end{array}$ \\
\hline $\begin{array}{l}\text { Yield Spread AAA- } \\
\text { Baa Corporate Bonds }\end{array}$ & $\begin{array}{c}3.93 \\
(0.4151)\end{array}$ & $\begin{array}{c}5.86 \\
(0.2100)\end{array}$ & $\begin{array}{c}0.67 \\
(0.9550)\end{array}$ \\
\hline Paper-Bill Spread & $\begin{array}{c}12.13 \\
(0.0164)\end{array}$ & $\begin{array}{c}11.69 \\
(0.0199)\end{array}$ & $\begin{array}{c}15.23 \\
(0.0043)\end{array}$ \\
\hline
\end{tabular}




\section{Table 5}

\section{Summary Statistics for New Commercial Paper Backup Lines of Credit, and Borrower Credit Rating and Size}

This table reports means and standard deviations for price and non-price terms for all new commercial paper backup lines of credit that appear on the Loan Pricing Corporation's Dealscan database, along with borrower credit rating and sales size. The sample reflects loans made to borrowers between 1991 and 2002, although Dealscan's coverage of the market for lending to large firms grew substantially during the sample period.

\begin{tabular}{|c|c|c|}
\hline & Mean & $\begin{array}{c}\text { Standard } \\
\text { Deviation }\end{array}$ \\
\hline Drawn spread over LIBOR (basis points) & 61 & 55 \\
\hline Undrawn Spread (basis points) & 13 & 9 \\
\hline Three-Month Treasury (basis points) & 466 & 126 \\
\hline Paper-Bill Spread (basis points) & 30 & 20 \\
\hline Term Structure: 5-Year Note - 3-Month Bill (basis points) & 98 & 95 \\
\hline Secured Indicator & 0.84 & - \\
\hline Maturity (months) & 18 & 15 \\
\hline Loan size (Millions \$s) & 635 & 1,032 \\
\hline Sales of borrower in year prior to loan (Millions $\$ \mathrm{~s}$ ) & 8,604 & 14,754 \\
\hline Moody's Aa or better indicator & 0.059 & - \\
\hline Moody's A1 indicator & 0.056 & - \\
\hline Moody's A2 indicator & 0.093 & - \\
\hline Moody's A3 indicator & 0.086 & - \\
\hline Moody's Baa1 indicator & 0.081 & - \\
\hline Moody's Baa2 indicator & 0.070 & - \\
\hline Moody's Baa3 indicator & 0.051 & - \\
\hline Moody's Ba indicator & 0.045 & - \\
\hline Moody's B indicator & 0.016 & - \\
\hline Un-rated indicator & 0.430 & \\
\hline
\end{tabular}




\section{Table 6 \\ Regressions of the Price of New Commercial Paper Lines of Credit \\ Panel A: All Commercial Paper Commitments}

\begin{tabular}{|c|c|c|c|c|}
\hline \multirow[b]{2}{*}{ Paper-Bill Spread } & \multicolumn{2}{|c|}{ Drawn all-in Spread } & \multicolumn{2}{|c|}{ Undrawn Spread } \\
\hline & $\begin{array}{c}-0.17 * * \\
(0.07)\end{array}$ & $\begin{array}{c}-0.16 * * \\
(0.06)\end{array}$ & $\begin{array}{c}-0.028 * * \\
(0.012)\end{array}$ & $\begin{array}{c}-0.034 * * \\
(0.013)\end{array}$ \\
\hline 3-Month Treasury & $\begin{array}{l}-0.01 \\
(0.02)\end{array}$ & $\begin{array}{c}0.01 \\
(0.02)\end{array}$ & $\begin{array}{l}0.007 * * \\
(0.003)\end{array}$ & $\begin{array}{l}-0.003 \\
(0.004)\end{array}$ \\
\hline Term Structure Spread & $\begin{array}{l}-0.02 \\
(0.02)\end{array}$ & $\begin{array}{c}0.01 \\
(0.02)\end{array}$ & $\begin{array}{l}0.016 * * \\
(0.004)\end{array}$ & $\begin{array}{l}-0.001 \\
(0.005)\end{array}$ \\
\hline Log of Sales & $\begin{array}{c}-6.52 * * \\
(0.91)\end{array}$ & $\begin{array}{c}-6.49 * * \\
(0.91)\end{array}$ & $\begin{array}{c}-1.16 * * \\
(0.17)\end{array}$ & $\begin{array}{c}-1.17 * * \\
(0.16)\end{array}$ \\
\hline $\begin{array}{l}\text { Moody's Ratings } \\
\text { Indicators }\end{array}$ & \multicolumn{4}{|c|}{--------------Included but not reported--------------- } \\
\hline Log-linear Time Trend & - & $\begin{array}{c}38.63 \\
(23.66)\end{array}$ & - & $\begin{array}{c}-25.45^{* *} \\
(5.43)\end{array}$ \\
\hline $\begin{array}{l}\mathrm{N} \\
\mathrm{R}^{2}\end{array}$ & $\begin{array}{c}1,720 \\
0.2102\end{array}$ & $\begin{array}{c}1,720 \\
0.2120\end{array}$ & $\begin{array}{c}1,520 \\
0.2095\end{array}$ & $\begin{array}{c}1,520 \\
0.2338\end{array}$ \\
\hline
\end{tabular}




\section{Table 6 \\ Regressions of the Price of New Commercial Paper Lines of Credit}

\section{Panel B: Drop Unrated Borrowers}

\begin{tabular}{|c|c|c|c|c|}
\hline \multirow[b]{2}{*}{ Paper-Bill Spread } & \multicolumn{2}{|c|}{ Drawn all-in Spread } & \multicolumn{2}{|c|}{ Undrawn Spread } \\
\hline & $\begin{array}{l}-0.16^{*} \\
(0.06)\end{array}$ & $\begin{array}{c}-0.14 * * \\
(0.06)\end{array}$ & $\begin{array}{c}-0.026 * * \\
(0.010)\end{array}$ & $\begin{array}{c}-0.032 * * \\
(0.010)\end{array}$ \\
\hline 3-Month Treasury & $\begin{array}{c}-0.03 * * \\
(0.01)\end{array}$ & $\begin{array}{l}-0.01 \\
(0.02)\end{array}$ & $\begin{array}{c}0.004 \\
(0.003)\end{array}$ & $\begin{array}{l}-0.004 \\
(0.003)\end{array}$ \\
\hline Term Structure Spread & $\begin{array}{c}-0.036 * * \\
(0.017)\end{array}$ & $\begin{array}{c}0.004 \\
(0.022)\end{array}$ & $\begin{array}{l}0.015 * * \\
(0.004)\end{array}$ & $\begin{array}{c}0.001 \\
(0.004)\end{array}$ \\
\hline Log of Sales & $\begin{array}{c}-3.42 * * \\
(0.72)\end{array}$ & $\begin{array}{c}-3.42 * * \\
(0.73)\end{array}$ & $\begin{array}{c}-0.86 * * \\
(0.15)\end{array}$ & $\begin{array}{c}-0.84 * * \\
(0.14)\end{array}$ \\
\hline $\begin{array}{l}\text { Moody's Ratings } \\
\text { Indicators }\end{array}$ & \multicolumn{4}{|c|}{----------- } \\
\hline Log-linear Time Trend & - & $\begin{array}{l}63.86 * * \\
(21.55)\end{array}$ & - & $\begin{array}{c}-21.91 * * \\
(4.54)\end{array}$ \\
\hline $\begin{array}{l}\mathrm{N} \\
\mathrm{R}^{2}\end{array}$ & $\begin{array}{c}1,294 \\
0.2501\end{array}$ & $\begin{array}{c}1,294 \\
0.2571\end{array}$ & $\begin{array}{c}1,181 \\
0.2550\end{array}$ & $\begin{array}{c}1,181 \\
0.2814\end{array}$ \\
\hline
\end{tabular}




\section{Table 7 \\ Regressions of the Price of New Commercial Paper Lines of Credit Including Non-Price Terms \\ Panel A: All Commercial Paper Commitments}

\begin{tabular}{|c|c|c|c|c|}
\hline \multirow[b]{2}{*}{ Paper-Bill Spread } & \multicolumn{2}{|c|}{ Drawn all-in Spread } & \multicolumn{2}{|c|}{ Undrawn Spread } \\
\hline & $\begin{array}{c}-0.18 * * \\
(0.06)\end{array}$ & $\begin{array}{c}-0.16 * * \\
(0.06)\end{array}$ & $\begin{array}{c}-0.021 * \\
(0.012)\end{array}$ & $\begin{array}{c}-0.027 * * \\
(0.012)\end{array}$ \\
\hline 3-Month Treasury & $\begin{array}{l}-0.014 \\
(0.015)\end{array}$ & $\begin{array}{c}0.006 \\
(0.018)\end{array}$ & $\begin{array}{c}0.004 \\
(0.003)\end{array}$ & $\begin{array}{l}-0.004 \\
(0.004)\end{array}$ \\
\hline Term Structure Spread & $\begin{array}{l}-0.018 \\
(0.020)\end{array}$ & $\begin{array}{c}0.014 \\
(0.024)\end{array}$ & $\begin{array}{l}0.012 * * \\
(0.004)\end{array}$ & $\begin{array}{l}-0.001 \\
(0.005)\end{array}$ \\
\hline Log of Sales & $\begin{array}{c}-3.87 * * \\
(0.79)\end{array}$ & $\begin{array}{c}-3.78 * * \\
(0.79)\end{array}$ & $\begin{array}{c}-0.77 * * \\
(0.17)\end{array}$ & $\begin{array}{c}-0.80 * * \\
(0.17)\end{array}$ \\
\hline Secured Indicator & $\begin{array}{l}4.41 * * \\
(2.09)\end{array}$ & $\begin{array}{l}4.85 * * \\
(2.08)\end{array}$ & $\begin{array}{l}0.75^{*} \\
(0.42)\end{array}$ & $\begin{array}{c}0.59 \\
(0.41)\end{array}$ \\
\hline Log of Maturity & $\begin{array}{l}-3.07 * \\
(1.58)\end{array}$ & $\begin{array}{l}-1.88 \\
(1.59)\end{array}$ & $\begin{array}{l}1.53 * * \\
(0.41)\end{array}$ & $\begin{array}{c}1.12 * * \\
(0.35)\end{array}$ \\
\hline Log of Loan Size & $\begin{array}{c}-8.87 * * \\
(1.30)\end{array}$ & $\begin{array}{c}-9.12 * * \\
(1.31)\end{array}$ & $\begin{array}{c}-1.37 * * \\
(0.23)\end{array}$ & $\begin{array}{c}-1.26 * * \\
(0.22)\end{array}$ \\
\hline $\begin{array}{l}\text { Moody's Ratings } \\
\text { Indicators }\end{array}$ & -------- & -----Incluc & ot reporte & --------- \\
\hline Log-linear Time Trend & - & $\begin{array}{l}54.79 * * \\
(23.42)\end{array}$ & - & $\begin{array}{c}-20.43 * * \\
(5.39)\end{array}$ \\
\hline $\begin{array}{l}\mathrm{N} \\
\mathrm{R}^{2}\end{array}$ & $\begin{array}{c}1,638 \\
0.2511\end{array}$ & $\begin{array}{c}1,638 \\
0.2545\end{array}$ & $\begin{array}{c}1,462 \\
0.2352\end{array}$ & $\begin{array}{c}1,462 \\
0.2562\end{array}$ \\
\hline
\end{tabular}


Table 7

Regressions of the Price of New Commercial Paper Lines of Credit Including Non-Price Terms

Panel B: Drop Unrated Borrowers

\begin{tabular}{|c|c|c|c|c|}
\hline \multirow[b]{2}{*}{ Paper-Bill Spread } & \multicolumn{2}{|c|}{ Drawn all-in Spread } & \multicolumn{2}{|c|}{ Undrawn Spread } \\
\hline & $\begin{array}{c}-0.17 * * \\
(0.06)\end{array}$ & $\begin{array}{c}-0.15 * * \\
(0.06)\end{array}$ & $\begin{array}{c}-0.023 * * \\
(0.010)\end{array}$ & $\begin{array}{c}-0.029 * * \\
(0.010)\end{array}$ \\
\hline 3-Month Treasury & $\begin{array}{c}-0.032 * * \\
(0.013)\end{array}$ & $\begin{array}{l}-0.008 \\
(0.016)\end{array}$ & $\begin{array}{l}0.002 \\
(0.003\end{array}$ & $\begin{array}{l}-0.005 \\
(0.003)\end{array}$ \\
\hline Term Structure Spread & $\begin{array}{c}-0.036^{*} \\
(0.018)\end{array}$ & $\begin{array}{c}0.003 \\
(0.022)\end{array}$ & $\begin{array}{l}0.010 * * \\
(0.004)\end{array}$ & $\begin{array}{l}-0.001 \\
(0.004)\end{array}$ \\
\hline Log of Sales & $\begin{array}{c}-2.12 * * \\
(0.66)\end{array}$ & $\begin{array}{c}-2.02 * * \\
(0.66)\end{array}$ & $\begin{array}{c}-0.55 * * \\
(0.16)\end{array}$ & $\begin{array}{c}-0.56 * * \\
(0.16)\end{array}$ \\
\hline Secured Indicator & $\begin{array}{l}4.28 * \\
(2.16)\end{array}$ & $\begin{array}{l}4.94 * * \\
(2.14)\end{array}$ & $\begin{array}{c}0.60 \\
(0.42)\end{array}$ & $\begin{array}{c}0.43 \\
(0.41)\end{array}$ \\
\hline Log of Maturity & $\begin{array}{l}-2.63 * \\
(1.42)\end{array}$ & $\begin{array}{l}-1.36 \\
(1.42)\end{array}$ & $\begin{array}{l}1.29 * * \\
(0.33)\end{array}$ & $\begin{array}{c}0.97 * * \\
(0.30)\end{array}$ \\
\hline Log of Loan Size & $\begin{array}{c}-3.85 * * \\
(1.22)\end{array}$ & $\begin{array}{c}-4.20 * * \\
(1.23)\end{array}$ & $\begin{array}{c}-0.94 * * \\
(0.24)\end{array}$ & $\begin{array}{c}-0.83 * * \\
(0.23)\end{array}$ \\
\hline $\begin{array}{l}\text { Moody's Ratings } \\
\text { Indicators }\end{array}$ & ------- & ----Includ & ot reported & --------- \\
\hline Log-linear Time Trend & - & $\begin{array}{l}66.39 * * \\
(22.21)\end{array}$ & - & $\begin{array}{c}-17.88 * * \\
(4.47)\end{array}$ \\
\hline $\begin{array}{l}\mathrm{N} \\
\mathrm{R}^{2}\end{array}$ & $\begin{array}{c}1,244 \\
0.2686\end{array}$ & $\begin{array}{c}1,244 \\
0.2757\end{array}$ & $\begin{array}{c}1,140 \\
0.2851\end{array}$ & $\begin{array}{c}1,140 \\
0.3016\end{array}$ \\
\hline
\end{tabular}




\section{Table 8}

\section{Regressions of Non-Price Terms of New Commercial Paper Lines of Credit}

Each column in this table reports a regression of the log of commitment amount, whether or not the loan is secured (in a probit) and the log of contractual maturity on new lines of credit issued to back commercial paper borrowing. Data on loan characteristics comes from the Loan Price Corporation's Dealscan database. Standard errors take account of clustering in the residual (i.e. non independence) that may occur for loans originated on the same day. Coefficients denoted ' $* *$ ' are statistically significantly different from zero at the 5\% level; those denoted '*' are statistically significantly different from zero at the $10 \%$ level.

\begin{tabular}{|c|c|c|c|c|c|c|}
\hline $\begin{array}{l}\text { Explanatory } \\
\text { Variables }\end{array}$ & \multicolumn{2}{|c|}{$\begin{array}{c}\text { Log of Commitment } \\
\text { Amount }\end{array}$} & \multicolumn{2}{|c|}{$\begin{array}{c}\text { Fraction of loans } \\
\text { Secured }\end{array}$} & \multicolumn{2}{|c|}{$\begin{array}{c}\text { Log of Contractual } \\
\text { Maturity }\end{array}$} \\
\hline $\begin{array}{l}\text { Paper-Bill } \\
\text { Spread }\end{array}$ & $\begin{array}{c}0.001 \\
(0.001)\end{array}$ & $\begin{array}{c}0.001 \\
(0.001)\end{array}$ & $\begin{array}{l}-0.0003 \\
(0.0006)\end{array}$ & $\begin{array}{l}-0.0005 \\
(0.0005)\end{array}$ & $\begin{array}{l}-0.002 * * \\
(0.0006)\end{array}$ & $\begin{array}{l}-0.002 * * \\
(0.0006)\end{array}$ \\
\hline $\begin{array}{l}\text { 3-Month } \\
\text { Treasury }\end{array}$ & $\begin{array}{c}-0.0009 * * \\
(0.0003)\end{array}$ & $\begin{array}{l}-0.0002 \\
(0.0003)\end{array}$ & $\begin{array}{c}0.0002 \\
(0.0002)\end{array}$ & $\begin{array}{l}-0.0001 \\
(0.0002)\end{array}$ & $\begin{array}{l}0.0007 * * \\
(0.0002)\end{array}$ & $\begin{array}{c}-0.0001 * * \\
(0.0002)\end{array}$ \\
\hline Term Spread & $\begin{array}{c}-0.0014 * * \\
(0.0004)\end{array}$ & $\begin{array}{l}-0.0006 \\
(0.0004)\end{array}$ & $\begin{array}{l}0.0004 * * \\
(0.0001)\end{array}$ & $\begin{array}{c}0.0001 * * \\
(0.0002)\end{array}$ & $\begin{array}{l}0.0017 * * \\
(0.0002)\end{array}$ & $\begin{array}{c}0.0003 \\
(0.0002)\end{array}$ \\
\hline Log of Sales & $\begin{array}{c}0.272 * * \\
(0.023)\end{array}$ & $\begin{array}{c}0.272 * * \\
(0.022)\end{array}$ & $\begin{array}{c}-0.013 * * \\
(0.006)\end{array}$ & $\begin{array}{c}-0.013 * * \\
(0.006)\end{array}$ & $\begin{array}{l}0.024 * * \\
(0.0085)\end{array}$ & $\begin{array}{l}0.022 * * \\
(0.0082)\end{array}$ \\
\hline $\begin{array}{l}\text { Ratings } \\
\text { Indicators }\end{array}$ & \multicolumn{6}{|c|}{----------------------Included but not Reported--------------------- } \\
\hline $\begin{array}{l}\text { Log-linear } \\
\text { Time Trend }\end{array}$ & - & $\begin{array}{l}1.834 * * \\
(0.432)\end{array}$ & - & $\begin{array}{c}-0.637 * * \\
(0.179)\end{array}$ & - & $\begin{array}{c}-2.003 * * \\
(0.235)\end{array}$ \\
\hline $\begin{array}{l}\mathrm{N} \\
\mathrm{R}^{2}\end{array}$ & $\begin{array}{c}2,035 \\
0.2531\end{array}$ & $\begin{array}{c}2,035 \\
0.2613\end{array}$ & $\begin{array}{c}2,036 \\
0.0476\end{array}$ & $\begin{array}{c}2,036 \\
0.0553\end{array}$ & $\begin{array}{c}1,875 \\
0.0641\end{array}$ & $\begin{array}{c}1,875 \\
0.1034\end{array}$ \\
\hline
\end{tabular}




\section{Appendix A: Theoretical Derivations}

A.1 The Basic equation.

Using $E[L]=0$ in the first line and the normality of $L$ in the third and fourth lines yields

$$
\begin{aligned}
\operatorname{Cov}\left(\alpha r_{D}, L\right) & =E\left[\alpha(L) r_{D} L\right] \\
= & \operatorname{Cov}\left(r_{D}, \alpha(L) L\right)+E\left[r_{D}\right] E[\alpha(L) L] \\
& =\frac{\sigma_{r_{D} L}}{\sigma_{L}^{2}} E\left[\alpha(L) L^{2}\right]+E\left[r_{D}\right] E[\alpha(L) L]
\end{aligned}
$$

The second line uses the fact that for the bivariate normal random variables $r_{D}, L$, we have

$$
\operatorname{Cov}\left(r_{D^{\prime}} f(L)\right)=\int f(L) E\left[r_{D} \mid L\right] \phi(L) d L-E\left[r_{D}\right] E[f(L)]=\operatorname{Cov}\left(r_{D}, L\right) \int f(L)\left(\frac{L}{\sigma_{L}^{2}}\right) \phi(L) d L
$$

where $\phi(L) \equiv \exp \left(-L^{2} / 2\right)$ is the standard normal density.

When $\alpha$ is twice differentiable, the normality of $L$ and Stein's lemma imply

$$
\begin{aligned}
\operatorname{Cov}\left(\alpha r_{D}, L\right) & =\operatorname{Cov}\left(r_{D}, \alpha(L) L\right)+E\left[r_{D}\right] E[\alpha(L) L] \\
& =E\left[(\alpha(L) L)^{\prime}\right] \sigma_{r_{D}, L}+E\left[r_{D}\right] E[\alpha(L) L] \\
& =\left(E\left[\alpha^{\prime}(L) L\right]+E[\alpha(L)]\right) \sigma_{r_{D}, L}+E\left[r_{D}\right] E[\alpha(L) L] \\
& =\left(E\left[\alpha^{\prime \prime}(L)\right] \sigma_{L}{ }^{2}+E[\alpha(L)]\right) \sigma_{r_{D}, L}+E\left[r_{D}\right] E[\alpha(L) L]
\end{aligned}
$$


A.2 The piecewise-linear case B)

Using the partial expectations of a function of the normally distributed $L$, we have

$$
\begin{aligned}
& \frac{d E\left[r_{L C}\right]}{d \sigma_{r_{D}, L}}=-\frac{\gamma}{\sigma_{L}^{2}} E\left[\alpha(L) L^{2}\right] \\
& =-\frac{\gamma}{\sigma_{L}^{2}}\left(E\left[\chi_{\left[-\infty, L_{h i}\right]} L^{2}\right]+\frac{L_{h i}}{L_{h i}-L_{l o}} E\left[\chi_{\left[L_{l o}, L_{h i}\right]} L^{2}\right]-\frac{1}{L_{h i}-L_{l o}} E\left[\chi_{\left[L_{l o}, L_{h i}\right]} L^{3}\right]\right) \\
& =-\gamma\left(\Phi\left(\frac{L_{l o}}{\sigma_{L}}\right)-\frac{L_{l o}}{\sigma_{L}} \phi\left(\frac{L_{l o}}{\sigma_{L}}\right)+\frac{L_{h i}}{L_{h i}-L_{l o}}\left[\Phi\left(\frac{L_{h i}}{\sigma_{L}}\right)-\frac{L_{h i}}{\sigma_{L}} \phi\left(\frac{L_{h i}}{\sigma_{L}}\right)-\Phi\left(\frac{L_{l o}}{\sigma_{L}}\right)+\frac{L_{l o}}{\sigma_{L}} \phi\left(\frac{L_{l o}}{\sigma_{L}}\right)\right]-\right. \\
& \left.-\frac{1}{L_{h i}-L_{l o}}\left[\left(\frac{L_{l o}^{2}}{\sigma_{L}}+2 \sigma_{L}\right) \phi\left(\frac{L_{l o}}{\sigma_{L}}\right)-\left(\frac{L_{h i}^{2}}{\sigma_{L}}+2 \sigma_{L}\right) \phi\left(\frac{L_{h i}}{\sigma_{L}}\right)\right]\right) \\
& =-\frac{\gamma \sigma_{L}}{L_{h i}-L_{l o}}\left[\frac{L_{h i}}{\sigma_{L}} \Phi\left(\frac{L_{h i}}{\sigma_{L}}\right)-\frac{L_{l o}}{\sigma_{L}} \Phi\left(\frac{L_{l o}}{\sigma_{L}}\right)+2\left(\phi\left(\frac{L_{h i}}{\sigma_{L}}\right)-\phi\left(\frac{L_{l o}}{\sigma_{L}}\right)\right)\right]
\end{aligned}
$$

where $\Phi$ and $\phi$ denote the standard normal cumulative distribution and density respectively. The relevant partial expectation formulas are

$$
\begin{aligned}
& E\left[\chi_{\left[-\infty, L^{*}\right]} L^{2}\right]=\sigma^{2} \int_{-\infty}^{\frac{L^{*}}{\sigma_{L}}} L^{2} \phi(L) d L=\sigma^{2}\left[\Phi\left(\frac{L^{*}}{\sigma_{L}}\right)-\left(\frac{L^{*}}{\sigma_{L}}\right) \phi\left(\frac{L^{*}}{\sigma_{L}}\right)\right] \\
& E\left[\chi_{\left[-\infty, L^{*}\right]} L^{3}\right]=\sigma^{3} \int_{-\infty}^{\frac{L^{*}}{\sigma_{L}}} L^{3} \phi(L) d L=-\sigma^{3}\left[\left(\frac{L^{*}}{\sigma_{L}}\right)^{2}+2\right] \phi\left(\frac{L^{*}}{\sigma_{L}}\right)
\end{aligned}
$$




\section{A.3 The step function}

At the limit $L_{\text {low }} \rightarrow L_{h} \alpha$ becomes the step function $\chi_{[-\infty, L h i]}$ and in that case, we have

$$
\frac{d E\left[r_{L C}\right]}{d \sigma_{r_{D}, L}}=-\gamma\left[\Phi\left(\frac{L_{h i}}{\sigma_{L}}\right)-\frac{L_{h i}}{\sigma_{L}} \phi\left(\frac{L_{h i}}{\sigma_{L}}\right)\right]
$$

We used

$$
\lim _{L_{l o w}-L_{h i}} \frac{\frac{L_{h i}}{\sigma_{L}} \Phi\left(\frac{L_{h i}}{\sigma_{L}}\right)-\frac{L_{l o}}{\sigma_{L}} \Phi\left(\frac{L_{l o}}{\sigma_{L}}\right)}{L_{h i}-L_{l o}}=\left[\frac{L}{\sigma_{L}} \Phi\left(\frac{L}{\sigma_{L}}\right)\right]_{\mid L=L i}^{\prime}=\frac{1}{\sigma_{L}}\left[\Phi\left(\frac{L_{h i}}{\sigma_{L}}\right)+\frac{L_{h i}}{\sigma_{L}} \phi\left(\frac{L_{h i}}{\sigma_{L}}\right)\right]
$$

and

$$
\lim _{L_{l o w} \rightarrow L_{h i}} \frac{\phi\left(\frac{L_{h i}}{\sigma_{L}}\right)-\phi\left(\frac{L_{l o}}{\sigma_{L}}\right)}{L_{h i}-L_{l o}}=\phi^{\prime}\left(\frac{L}{\sigma_{L}}\right)=-\frac{L_{h i}}{\sigma_{L}^{2}} \phi\left(\frac{L_{h i}}{\sigma_{L}}\right)
$$




\section{Appendix B: Bank-level Reaction to Market Spreads}

The aggregate analysis offered in the text suggests that banks enjoy cheap funding when the commercial paper market tightens. In this appendix, we test how loan takedown behavior varies across banks in response to interest rates and the paper-bill spread.

Direct data on actual loan take downs from loan commitments are not available. We can, however, observe overall loan growth at quarterly frequency, and test whether those banks with more pre-existing loan commitments experience greater increases in loan growth when market spreads widen. If demand for loan take downs really increases with increases in the commercial paper spread, then we ought to be able to show that banks with more pre-existing loan commitments react more to market shocks than other banks. At the same time, the growth in liquid assets with the $\mathrm{CP}$ spread observed in the aggregate data ought to occur at all banks, regardless of their level of loan commitments -- an across-the-board growth in liquid assets would reflect the better funding availability to banks generally. ${ }^{21}$

We construct a panel data set for all banking organizations using data from 1991 to $2000 .{ }^{22}$ Rates of change in assets, loans and securities come from the Reports of Income and Condition (the "Call Report"). As noted above, ideally we would like to observe the data at a higher frequency, but detailed bank-level data are not available beyond quarterly intervals. The sample begins in the first quarter of 1991 because the banking agencies only began to collect data on unused loan commitments then.

\footnotetext{
${ }^{21}$ The interbank credit market may be the means by which a general inflow of funding into the banking system is funneled to those banks experiencing the largest increases in loan demand.

${ }^{22}$ Following Kashyap et al (2002), we use the banking organization as the relevant unit of observation, rather than the bank. This means that we first aggregate the bank-level data from the call report up to the holding company level. For example, for a bank holding company owning two banks, we would sum the balance sheet items for each bank first and create a single observation reflecting this banking company's balance sheet (and off balance sheet) characteristics.
} 
The panel data set is unbalanced due to merger and acquisition activity that occurred during the sample period. We drop observations in which a banking organization's total assets grew by more than 10 percent during a single quarter. In this way, we can be sure that large changes in a bank's operations stemming from its M\&A activity are not skewing our results. In addition, because the dependent variables are growth rates, there are substantial outliers in the panel. We therefore Winsorize the data at the $1^{\text {st }}$ and $99^{\text {th }}$ percentiles of the distribution. That is, for each observation that lies below the $1^{\text {st }}$ percentile of the distribution, we use the value at the $1^{\text {st }}$ percentile; for each observation that lies above the $99^{\text {th }}$ percentile of the distribution, we use the value $a t$ the $99^{\text {th }}$ percentile. ${ }^{23}$

Appendix Table 1 reports the summary statistics for the variables in the panel data set. The quarterly growth in assets averaged (median) 1.5 percent across banks and time, and the inter-quartile range varied from -0.5 percent to 4.0 percent. For the quarterly change in loans (normalized by assets), the distribution varies somewhat less than for asset growth, whereas the change in liquid assets, sensibly, displayed substantially more variation, ranging from -1.8 percent at the $25^{\text {th }}$ percentile to 2.1 percent at the $75^{\text {th }}$ percentile with a median of about zero.

Appendix Table 1 also reports the ratio of unused lines of credit divided by unused lines plus total on-balance-sheet loans. This variable is our measure of the extent to which a bank has promised to provide liquidity insurance to its borrowers. The unused commitments ratio had a median value of 0.109 , ranging from 0.058 at the $25^{\text {th }}$ percentile of the distributions to 0.167 at the $75^{\text {th }}$ percentile.

Appendix Table 2 reports the panel regressions for the three rates-of-change variables. We include the same interest rate variables used in the aggregate analysis, but now, rather than

\footnotetext{
${ }^{23}$ Our statistical conclusions are not affected by Winsorizing these data, although the magnitude of the coefficients and standard errors is affected.
} 
using high-frequency data, we use averages over the whole quarter. We also include interaction terms between the interest rate variables and each bank's unused commitment ratio (as of the end of the previous quarter). Thus, the coefficients on these interaction terms test whether a bank's response to interest rate shocks changes with the extent of its pre-existing loan commitments. We also include that bank's beginning-of-period capital-asset ratio and its interaction with the CP spread to test whether banks with lower insolvency risk enjoy larger funding inflows when the CP spread widens. To control for other cross-bank heterogeneity, we include the log of assets as of the beginning of the period as control variables and bank-level fixed effects. In addition, we report the models with (in panel A) and without (in panel B) quarterly time fixed effects.

As shown in both panels of Appendix Table 2, the effects of increases in the paper-bill spread on asset growth and loan growth are greater for banks with more pre-existing lines of credit. That is, the interaction of the paper-bill spread with the unused loan commitment ratio is statistically significant (at the one percent level). The greater loan-growth suggests that banks with more commitments experience more take-down demand when CP spreads widen. Just as in the aggregate analysis, we again see increases in the growth of liquid assets when the paper-bill spread widens, suggesting strong funding availability for banks during periods of market tightness. But we do not see any difference in how the liquid-asset growth rate responds to spreads across banks; regardless of their level of loan commitments, all banks experience increases in liquid assets following increases in the commercial paper spread. Similarly, the coefficient on initial bank capital is positive and significant for all three variables, but the interaction with the $\mathrm{CP}$ spread is not. Thus, there seems to be no evidence that banks with stronger balance sheets - banks that might be perceived to be relatively safe - experience large funding inflows during periods of wide spread. 
Taken as a whole, the results indicate that when markets become tight, funding becomes more available to banks across that board. Neither banks with greater pre-existing loan commitments nor banks with better balance sheets (more capital) seem to receive more funding inflows. We take this as evidence that market participants view the bank system as a safe haven for funds, probably because of explicit and implicit support provided by government safety nets. 


\section{Appendix Table 1 \\ Summary Statistics for Quarterly Bank-Level Panel Data}

This table reports summary statistics for growth rates in assets, loans and liquid assets (cash+securities+fed funds sold-fed funds purchased), along with the ratio of unused loan commitments to unused commitments plus total loans. Change in loans and liquid assets are normalized by beginning-of-period assets. The sample is based on a panel of all U.S. banks with assets greater than \$100 million for each quarter from 1991 to 2000, from the Reports of Income and Condition. All banks with asset growth greater the 10 percent during a quarter are dropped during that quarter so that large mergers will not skew the growth rates. Since the variables display large outliers, the data have been Winsorized at the $1^{\text {st }}$ and $99^{\text {th }}$ percentile. Also reported is the paper-bill spread averaged over each quarter, defined as the 3-month commercial paper rate for highly rated borrowers minus the 3-month Treasury Bill rate, and the 3-month Treasury Bill rate, also averaged over each quarter in the 1991 to 2000 period.

Quarterly Growth in Assets

$\Delta$ Loans / $_{\text {Assets }}$

$\Delta$ Liquid Assets / Assets ${ }_{\mathrm{t}-1}$

Unused commitments /

(Unused commitments+Loans)

Paper-Bill Spread

3-Month Treasury Bill Rate
0.35

0.40

0.48

4.05 $75^{\text {th }}$

\begin{tabular}{ccc} 
Percentile & Median & Percentile \\
\hline$-0.5 \%$ & $1.5 \%$ & $4.0 \%$ \\
$-0.3 \%$ & $1.0 \%$ & $2.4 \%$ \\
$-1.8 \%$ & $0.07 \%$ & $2.1 \%$ \\
0.058 & 0.109 & 0.167 \\
0.35 & 0.40 & 0.48 \\
4.05 & 5.00 & 5.28 \\
\hline
\end{tabular}




\section{Appendix Table 2 \\ Fixed Effects Regressions of Growth in Assets, Loans and Liquid Assets on the Paper-Bill Spread, Interest Rates and Interactions \\ Panel A: No control for trends}

Each column in this table reports a fixed effects regression of three bank-level variables: the growth in assets, the growth in loans and the growth in liquid assets. The sample is based on a panel of all U.S. banks with assets greater than $\$ 100$ million for each quarter from 1991 to 2000, from the Reports of Income and Condition. All banks with asset growth greater the 10 percent during a quarter are dropped during that quarter so that large mergers will not skew the changes in lending and deposits. Since the growth rates display large outliers, these data have been Winsorized at the $1^{\text {st }}$ and $99^{\text {th }}$ percentile. Also reported is the paper-bill spread averaged over each quarter, defined as the 3-month commercial paper rate for highly rated borrowers minus the 3-month Treasury Bill rate, and the 3-month Treasury Bill rate, also averaged over each quarter in the 1991 to 2000 period. Standard errors appear below coefficients. Coefficients denoted '**' are statistically significantly different from zero at the $5 \%$ level; those denoted ' $*$ ' are statistically significantly different from zero at the $10 \%$ level.

\section{Dependent Variables}

\begin{tabular}{|c|c|c|c|}
\hline & $\begin{array}{l}\text { Asset } \\
\text { Growth }\end{array}$ & $\begin{array}{l}\Delta \text { Loans } \\
\text { / }_{\text {Assets }} \text { t- } 1\end{array}$ & $\begin{array}{l}\Delta \text { Liquid Assets } \\
\text { / } \text { Assets }_{\mathrm{t}-1}\end{array}$ \\
\hline Paper-Bill Spread & $\begin{array}{c}0.009 * * \\
(0.003)\end{array}$ & $\begin{array}{c}0.001 \\
(0.002)\end{array}$ & $\begin{array}{c}0.009 * * \\
(0.002)\end{array}$ \\
\hline 3-Month Treasury & $\begin{array}{l}0.002 * * \\
(0.0002)\end{array}$ & $\begin{array}{l}0.002 * * \\
(0.0001)\end{array}$ & $\begin{array}{l}-0.001 * * \\
(0.0002)\end{array}$ \\
\hline Unused Commitments $_{\mathrm{t}-1}$ & $\begin{array}{c}0.031 * * \\
(0.008)\end{array}$ & $\begin{array}{c}0.114 * * \\
(0.005)\end{array}$ & $\begin{array}{c}-0.126 * * \\
(0.007)\end{array}$ \\
\hline $\begin{array}{l}\text { Unused Commitments }_{\mathrm{t}-1} * \\
\text { Paper-Bill Spread }\end{array}$ & $\begin{array}{c}0.064 * * \\
(0.010)\end{array}$ & $\begin{array}{c}0.061 * * \\
(0.007)\end{array}$ & $\begin{array}{l}-0.007 \\
(0.010)\end{array}$ \\
\hline $\begin{array}{l}\text { Unused Commitments }{ }_{\mathrm{t}-1} * \\
\text { 3-Month Treasury }\end{array}$ & $\begin{array}{c}-0.002 \\
(0.0013)\end{array}$ & $\begin{array}{l}-0.005 * * \\
(0.0009)\end{array}$ & $\begin{array}{l}0.009 * * \\
(0.001)\end{array}$ \\
\hline Capital-Asset Ratio $_{\mathrm{t}-1}$ & $\begin{array}{l}0.201 * * \\
(0.013)\end{array}$ & $\begin{array}{c}0.057 * * \\
(0.009)\end{array}$ & $\begin{array}{l}0.102 * * \\
(0.012)\end{array}$ \\
\hline $\begin{array}{l}\text { Capital-Asset Ratio } \\
\text { Paper-Bill Spread }\end{array}$ & $\begin{array}{c}0.013 \\
(0.025)\end{array}$ & $\begin{array}{l}-0.018 \\
(0.017)\end{array}$ & $\begin{array}{l}0.0004 \\
(0.025)\end{array}$ \\
\hline Log of Assets ${ }_{t-1}$ & $\begin{array}{l}-0.013 * * \\
(0.0005)\end{array}$ & $\begin{array}{c}-0.004 * * \\
(0.0003) \\
\end{array}$ & $\begin{array}{l}-0.006 * * \\
(0.0005) \\
\end{array}$ \\
\hline Firm Dummies & Yes & Yes & Yes \\
\hline Quarterly time dummies & No & No & No \\
\hline $\begin{array}{l}\mathrm{N} \\
\text { Within } \mathrm{R}^{2}\end{array}$ & $\begin{array}{c}110,201 \\
0.018\end{array}$ & $\begin{array}{c}110,201 \\
0.026\end{array}$ & $\begin{array}{c}110,201 \\
0.009\end{array}$ \\
\hline
\end{tabular}




\section{Appendix Table 2 \\ Fixed Effects Regressions of Growth in Assets, Loans and Liquid Assets on the Paper-Bill Spread, Interest Rates and Interactions}

Panel B: Year Fixed Effects

Each column in this table reports a fixed effects regression of three bank-level variables: the growth in assets, the growth in loans and the growth in liquid assets. The sample is based on a panel of all U.S. banks with assets greater than $\$ 100$ million for each quarter from 1991 to 2000, from the Reports of Income and Condition. All banks with asset growth greater the 10 percent during a quarter are dropped during that quarter so that large mergers will not skew the changes in lending and deposits. Since the growth rates display large outliers, these data have been Winsorized at the $1^{\text {st }}$ and $99^{\text {th }}$ percentile. Also reported is the paper-bill spread averaged over each quarter, defined as the 3-month commercial paper rate for highly rated borrowers minus the 3-month Treasury Bill rate, and the 3-month Treasury Bill rate, also averaged over each quarter in the 1991 to 2000 period. Standard errors appear below coefficients. Coefficients denoted '**' are statistically significantly different from zero at the $5 \%$ level; those denoted ' $*$ ' are statistically significantly different from zero at the $10 \%$ level.

\section{Dependent Variables}

\begin{tabular}{|c|c|c|c|}
\hline & $\begin{array}{l}\text { Asset } \\
\text { Growth }\end{array}$ & $\begin{array}{l}\Delta \text { Loans } \\
/ \text { Assets }_{\mathrm{t}-1}\end{array}$ & $\begin{array}{l}\Delta \text { Liquid Assets } \\
\text { / } \text { Assets }_{\mathrm{t}-1}\end{array}$ \\
\hline Paper-Bill Spread & - & - & - \\
\hline 3-Month Treasury & - & - & - \\
\hline Unused Commitments $_{\mathrm{t}-1}$ & $\begin{array}{c}0.033 * * \\
(0.007)\end{array}$ & $\begin{array}{l}0.109 * * \\
(0.005)\end{array}$ & $\begin{array}{l}-0.114 * * \\
(0.007)\end{array}$ \\
\hline $\begin{array}{l}\text { Unused Commitments }_{\mathrm{t}-1} * \\
\text { Paper-Bill Spread }\end{array}$ & $\begin{array}{c}0.067 * * \\
(0.010)\end{array}$ & $\begin{array}{c}0.058 * * \\
(0.007)\end{array}$ & $\begin{array}{l}0.0002 \\
(0.010)\end{array}$ \\
\hline $\begin{array}{l}\text { Unused Commitments }{ }_{\mathrm{t}-1} * \\
\text { 3-Month Treasury }\end{array}$ & $\begin{array}{l}-0.002 * \\
(0.0013)\end{array}$ & $\begin{array}{l}-0.005 * * \\
(0.0009)\end{array}$ & $\begin{array}{l}0.008 * * \\
(0.001)\end{array}$ \\
\hline Capital-Asset Ratio $_{\mathrm{t}-1}$ & $\begin{array}{c}0.195 * * \\
(0.013)\end{array}$ & $\begin{array}{c}0.057 * * \\
(0.009)\end{array}$ & $\begin{array}{l}0.101 * * \\
(0.012)\end{array}$ \\
\hline $\begin{array}{l}\text { Capital-Asset Ratio }{ }_{\mathrm{t}-1} * \\
\text { Paper-Bill Spread }\end{array}$ & $\begin{array}{c}0.002 \\
(0.025)\end{array}$ & $\begin{array}{l}-0.015 \\
(0.017)\end{array}$ & $\begin{array}{l}-0.010 \\
(0.024)\end{array}$ \\
\hline Log of Assets $_{t-1}$ & $\begin{array}{c}-0.014 * * \\
(0.001)\end{array}$ & $\begin{array}{l}-0.003 * * \\
(0.0004)\end{array}$ & $\begin{array}{l}-0.006 * * \\
(0.0006)\end{array}$ \\
\hline Firm Dummies & Yes & Yes & Yes \\
\hline Quarterly time dummies & Yes & Yes & Yes \\
\hline $\mathrm{N}$ & 110,201 & 110,201 & 110,201 \\
\hline Within $\mathrm{R}^{2}$ & 0.029 & 0.045 & 0.036 \\
\hline
\end{tabular}


Figure 1

\section{Banks}

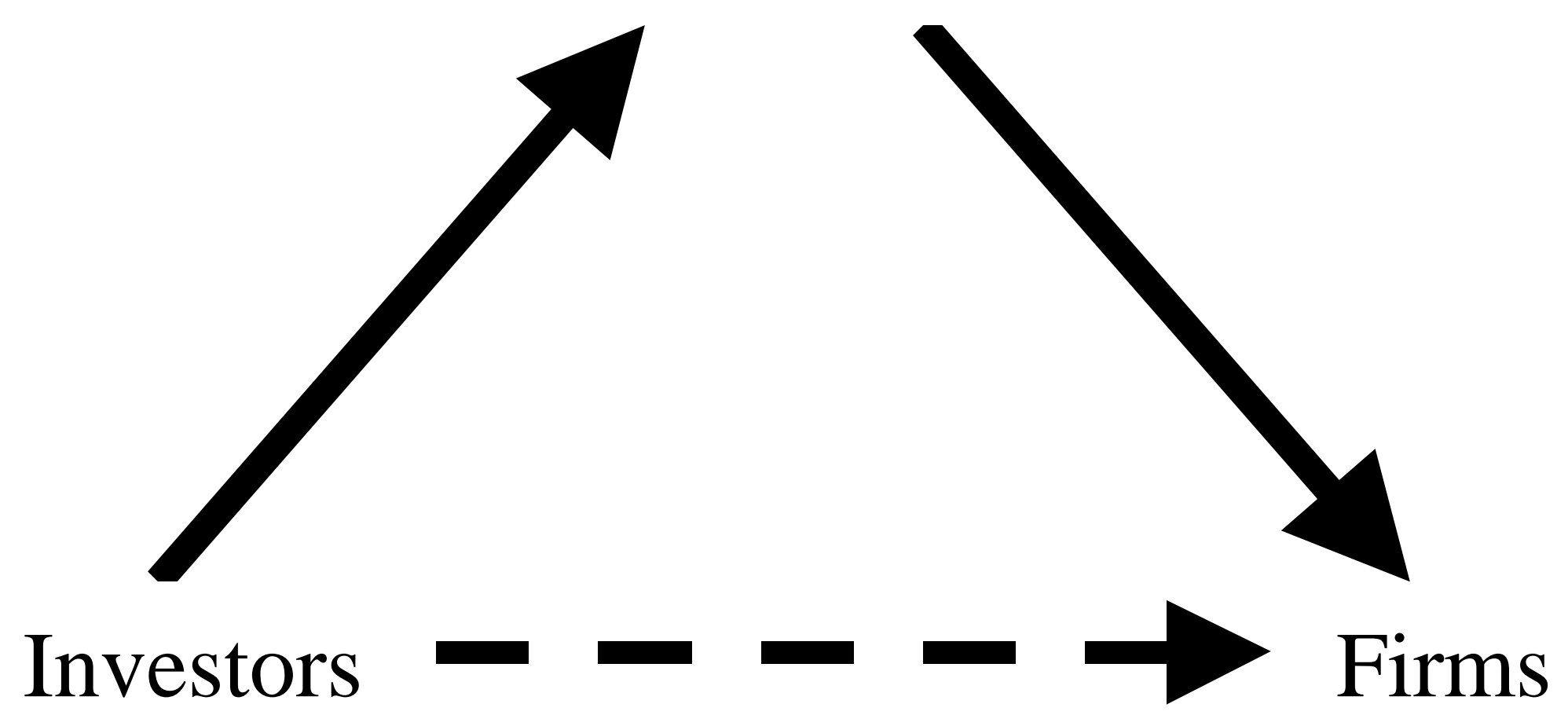




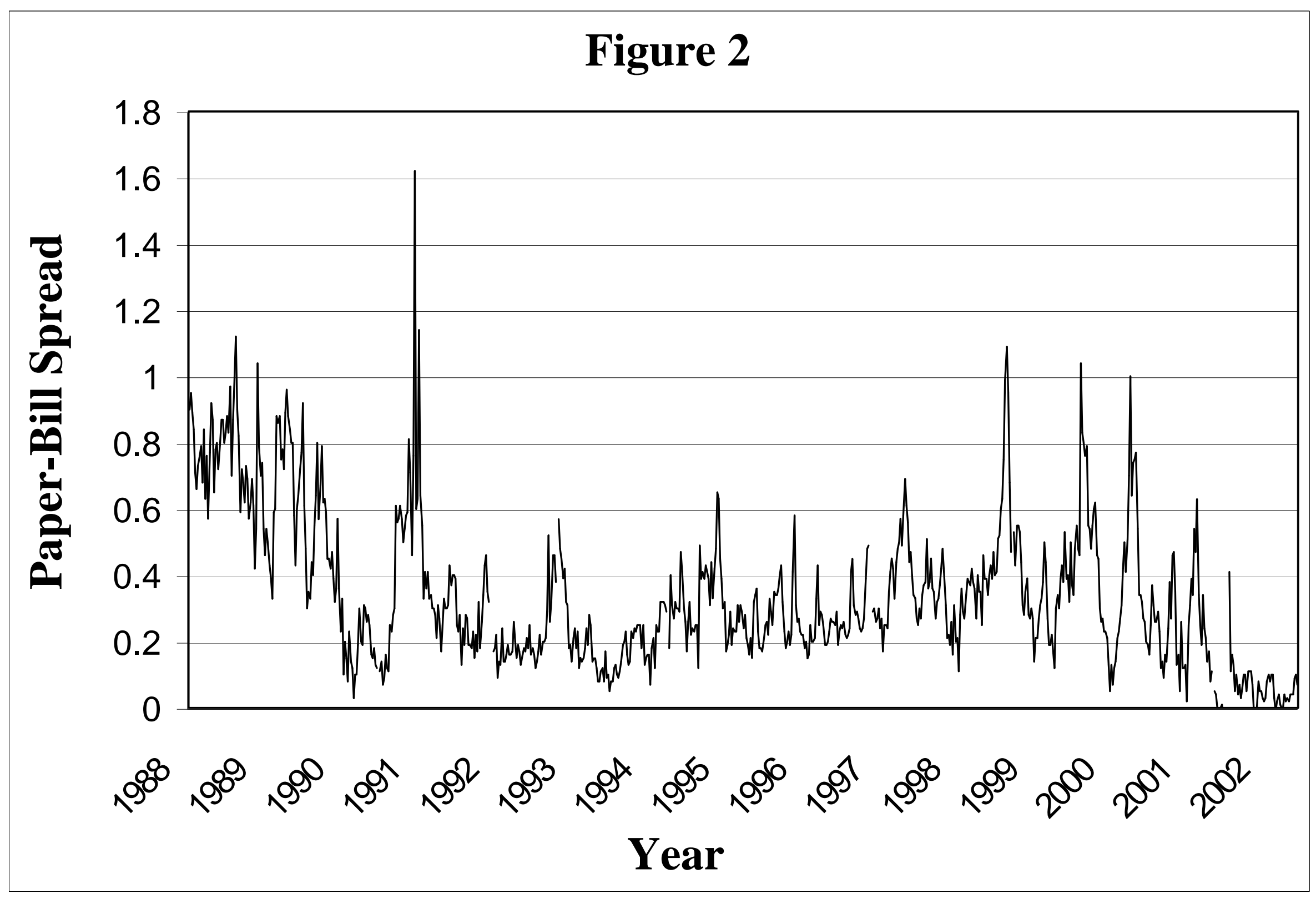




\section{Figure 3: Assets Impulse Responses}

Graph Titles: IRFname, Impulse Variable, Response Variable
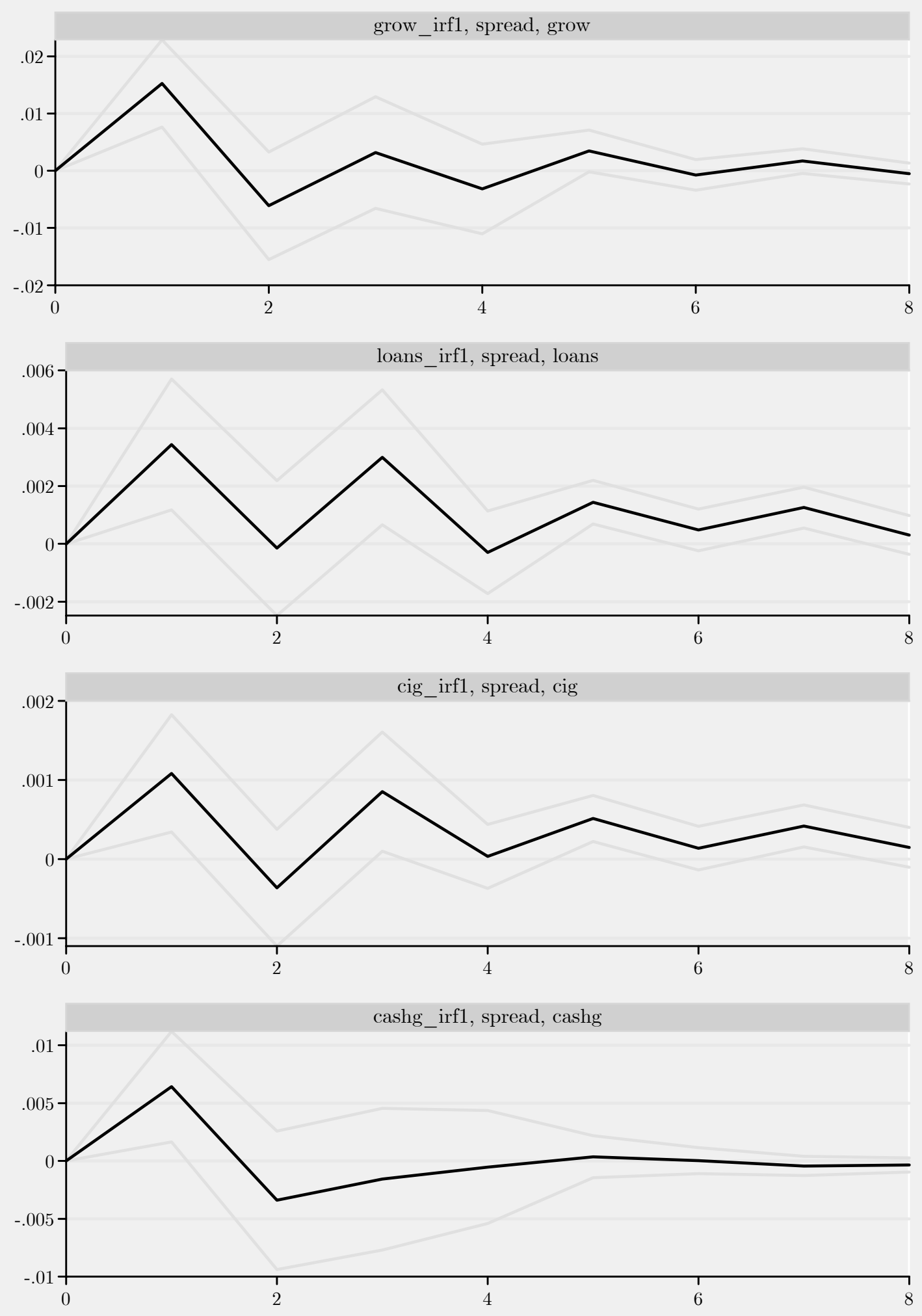


\section{Figure 3: Liabilities Impulse Responses}

Graph Titles: IRFname, Impulse Variable, Response Variable
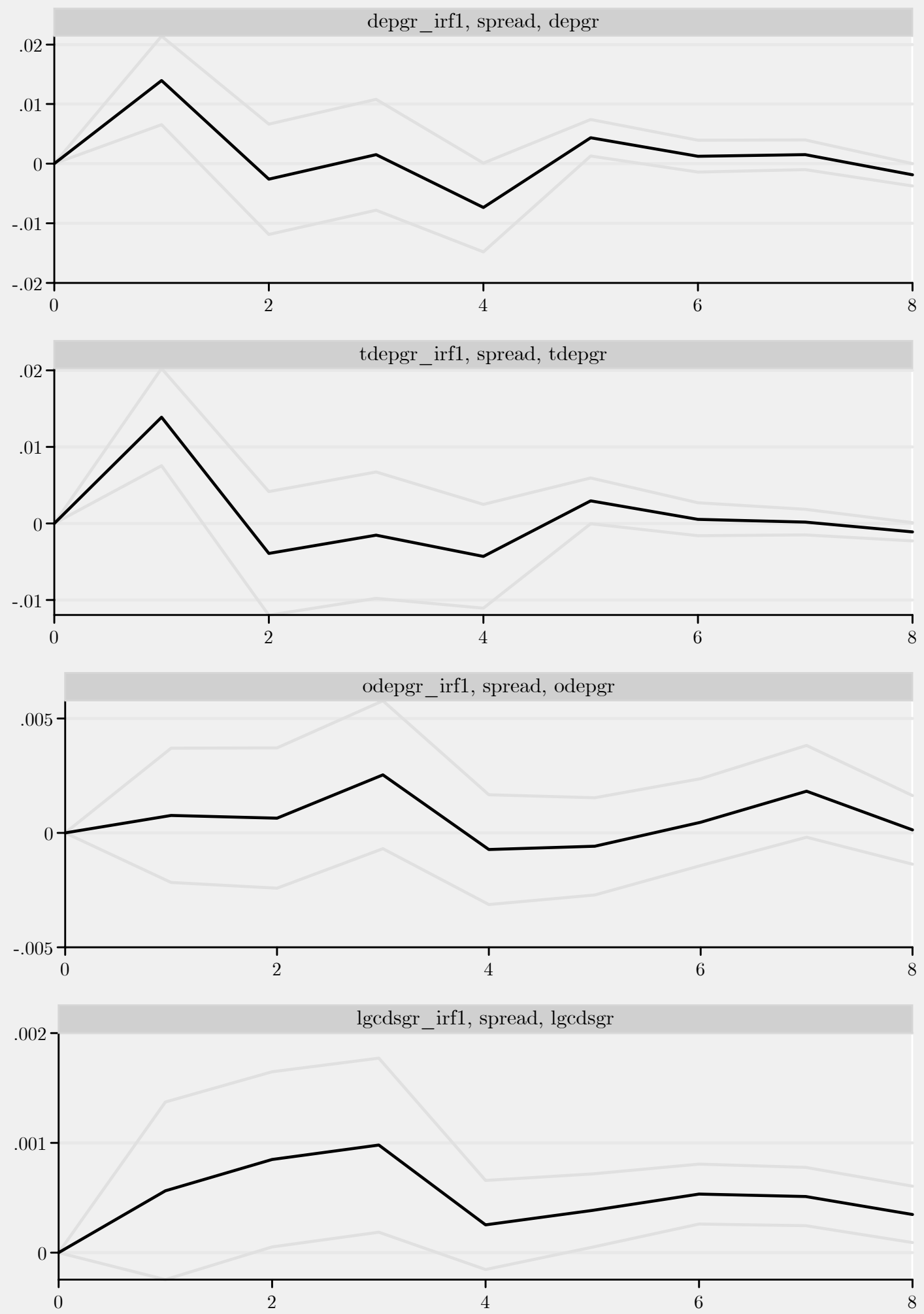


\section{Figure 3: Rates Impulse Responses}

Graph Titles: IRFname, Impulse Variable, Response Variable
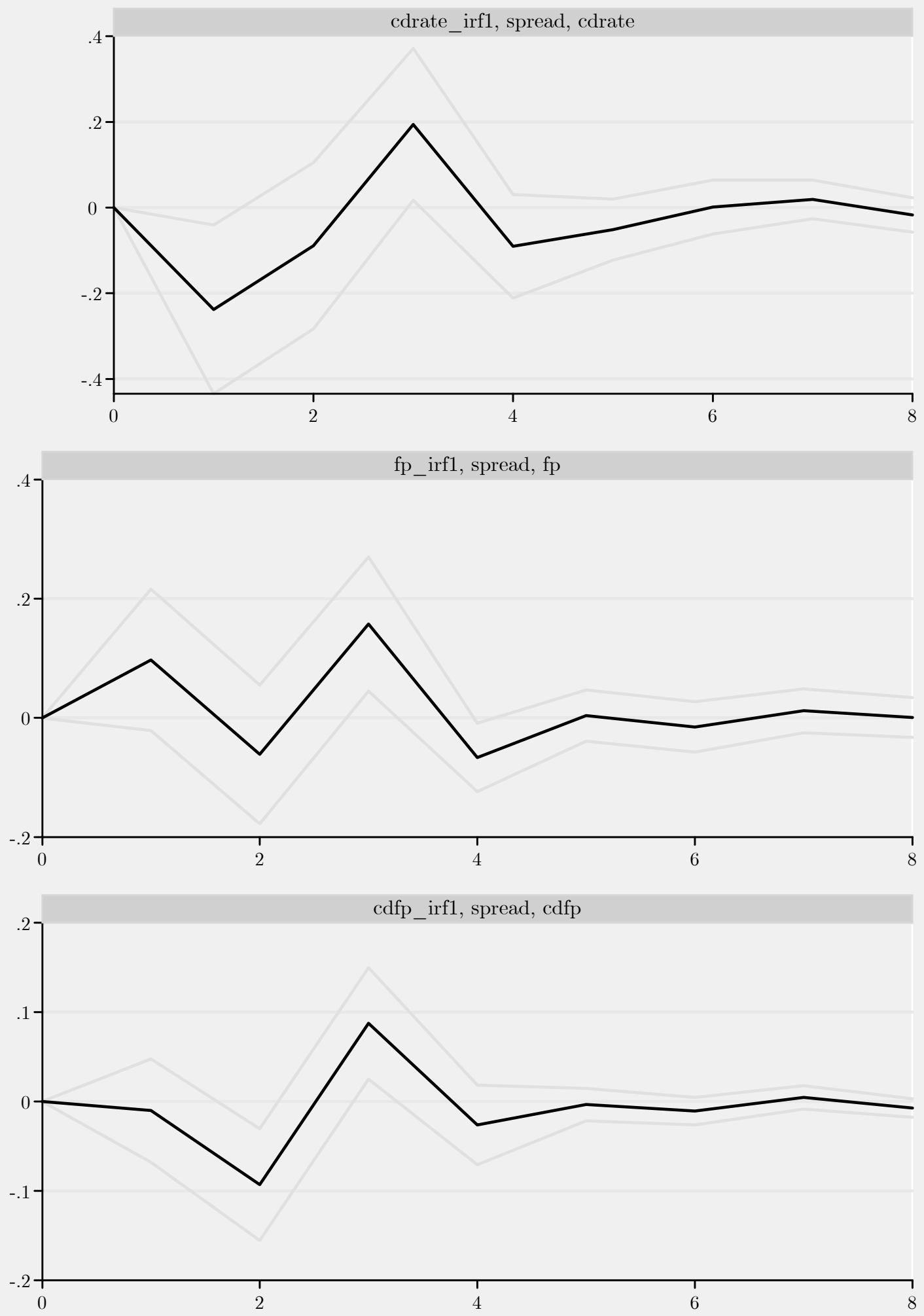